Studia Judaica 21 (2018), nr 2 (42), s. 333-371

doi:10.4467/24500100STJ.18.015.10266

Marta Grudzińska

Marta Kubiszyn

\title{
„To was tutaj tak strasznie biją? [...] Nie, nas nie. Tylko Żydów": Żydzi w obozie na Majdanku w świetle relacji polskich więźniów ${ }^{1}$
}

\author{
"SO THEY BEAT YOU REALLY HARD HERE? NO, NOT US, ONLY THE JEWS": \\ JEWISH VICTIMHOOD INSIDE THE MAJDANEK CAMP IN POLISH PRISONERS' \\ TESTIMONIES
}

\begin{abstract}
The article draws on a source material from The State Museum Majdanek Archives, a collection of video testimonies recorded in 1987-1989, to develop a fuller picture of social relations among prisoners of different ethnic backgrounds at the Majdanek Concentration Camp. From the fall of 1941 through July 1944, Majdanek functioned as a killing center and a concentration camp for about 150,000 prisoners from different European countries. Drawing on video testimonies as a type of oral history, the article traces the perception of Jews in the camp by Polish prisoners, their social interactions, and the interethnic social boundaries shaped by camp life.
\end{abstract}

Keywords: Majdanek, KL Lublin, Jews, Poles, prisoners, oral history, video interviews, memory, Holocaust.

Słowa kluczowe: Majdanek, KL Lublin, Żydzi, Polacy, więźniowie, oral history, wywiady wideo, pamięć, Zagłada.

${ }^{1}$ Przy rozróżnieniu między „Polacy” (polscy więźniowie) a „Żydzi” przyjęto etniczne znaczenie tych pojęć. Żydzi byli przywożeni do obozu ze względu na założenia polityki III Rzeszy, której celem było całkowite zgładzenie tej grupy. Podziały na przynależność państwową, stosowane wobec innych grup, Żydów nie obejmowały. W obozie wyróżniało ich oznakowanie gwiazdą Dawida, którą nosili żydowscy więźniowie przywożeni z Polski i innych krajów Europy. 


\section{Żydowscy więźniowie w obozie na Majdanku jako przedmiot badań}

Przekonanie, że Zagłada Żydów w czasie II wojny światowej jest jednym z najbardziej traumatycznych wydarzeń XX w., na którym ukształtowały się zręby powojennej świadomości historycznej, etycznej oraz filozofii, przez wielu badaczy uznawane jest za istotny topos współczesnej humanistyki ${ }^{2}$. Jednocześnie jednak, jak wynika z prowadzonych w ostatnich latach badań empirycznych, pomimo iż eksterminacja Żydów w znacznej mierze dokonała się na okupowanych ziemiach polskich, wielu współczesnych Polaków nie uznaje Zagłady za ważną część historii swojego państwa ani za wyjątkowe wydarzenie w dziejach XX stulecia ${ }^{3}$. Taki sposób postrzegania tamtych wydarzeń może być - jak się wydaje - związany m.in. z procesami kształtowania się w powojennej Polsce narracji historycznej dotyczącej okresu okupacji pod wpływem różnego rodzaju czynników politycznych i społecznych. Choć zaraz po zakończeniu działań wojennych podjęte zostały badania nad losami Żydów w czasie wojny, już w 1949 r. - wraz z zacieśnianiem się reżimu stalinowskiego - rozpoczął się trwający kilkadziesiąt lat proces marginalizowania tej problematyki ${ }^{4}$.

${ }^{2}$ Zob. m.in.: Jacek Zychowicz, Historiografia Auschwitzu: od krytycznej negacji do instrumentalizacji, [w:] Pamięć Shoah. Kulturowe reprezentacje i praktyki upamiętniania, red. Tomasz Majewski, Anna Zeidler-Janiszewska, Maria Wójcik, Łódź 2009, s. 455 i n.

${ }^{3}$ Zob. Marek Kucia, Auschwitz jako fakt społeczny. Historia, wspótczesność i świadomość społeczna KL Auschwitz w Polsce, Kraków 2005; tenże, Optymistyczne dane - niepokojące pytania - radykalne wnioski, [w:] Auschwitz i Holokaust. Dylematy i wyzwania polskiej edukacji, red. Piotr Trojański, Oświęcim 2008, s. 43-44; Michał Bilewicz, Społeczna pamięć Holokaustu i Auschwitz wśród licealistów: wokót projektu badawczego „Trudne pytania”, [w:] Auschwitz i Holokaust..., s. 34; Piotr Trojański, Upolitycznienie i instrumentalizacja pamięci ofiar Auschwitz (1946-1955), [w:] Stowa w stużbie nienawiści, red. Alicja Bartuś, Oświęcim 2013, s. 337; Barbara Szacka, II wojna światowa w pamięci rodzinnej, [w:] Między codziennościa a wielka historią. Druga wojna światowa w pamięci zbiorowej społeczeństwa polskiego, [Aut.] Piotr T. Kwiatkowski, Lech Nijakowski, Barbara Szacka, Andrzej Szpociński, Gdańsk-Warszawa 2010, s. 107, 125; Piotr T. Kwiatkowski, Wprowadzenie. Doświadczenie II wojny światowej w badaniach socjologicznych, [w:] Między codziennościa a wielka historia ..., s. 16-20; tenże, II wojna światowa jako doświadczenie narodowe, [w:] Między codziennościa a wielka historia..., s. 144.

${ }^{4}$ Bilewicz, Społeczna pamięć..., s. 27; Michael Steinlauf, Pamięć nieprzyswojona. Polska pamięć Zagłady, tłum. Agata Tomaszewska, Warszawa 2001; Zofia Wóycicka, Przerwana żałoba. Polskie spory wokót pamięci nazistowskich obozów koncentracyjnych i zagłady 1944-1950, Warszawa 2009. Zofia Wóycicka w przywołanej tu pracy (s. 109) wśród przyczyn sporów o interpretację i sposób upamiętniania Zagłady wylicza: antysemityzm, rywalizację ofiar, poczucie obcości i izolacji, a następnie emigrację części ocalałych, które sprawiły, że Żydzi zostali wykluczeni ze wspólnoty ofiar. 
Określoną rolę w owym marginalizowaniu odgrywały miejsca pamięci muzea, w tym utworzone jesienią 1944 r. Państwowe Muzeum na Majdanku w Lublinie (dalej: PMM), będące pierwszym muzeum martyrologicznym w Europie i na świecie działającym w miejscu byłego obozu. Od początku istnienia tej instytucji wyraźne było wykorzystywanie jej do celów propagandowych. Podkreślanie roli Związku Radzieckiego w wyzwalaniu okupowanej Polski, mające służyć legitymizacji nowej władzy, sprzyjało kreowaniu narracji muzealnej, w której dominowało podejście narodowe ${ }^{5}$. Antysemicka kampania marcowa 1968 r. negatywnie wpłynęła na proces upamiętniania Zagłady ${ }^{6}$ - m.in. na skutek tamtych wydarzeń problematyka żydowska zniknęła z popularnego przekazu wiedzy na temat historii Konzentrationslager Lublin (dalej: KL Lublin) ${ }^{7}$. Odsłonięcie Pomnika Walki i Męczeństwa oraz Mauzoleum na terenie PMM w 1969 r. potraktowane zostało jako wiec antywojenny, w trakcie którego potępiono imperializm amerykański i izraelski na Bliskim Wschodzie ${ }^{8}$. Podczas uroczystości otwarcia oraz w artykułach prasowych nie pojawiały się odniesienia do Żydów jako znaczącej grupy więźniów i ofiar obozu oraz ofiar egzekucji 3 listopada 1943 r. ${ }^{9}$

${ }^{5}$ Zagadnienia te można analizować, odwołując się do prezentowanych w PMM ekspozycji stałych, będących ważną częścią działalności Muzeum w obszarze edukacji i propagandy politycznej. Twórcy pierwszej wystawy, pokazywanej w latach 1945-1949, podkreślali znaczenie obozu jako miejsca zagłady Polaków dokonującej się na tle eksterminacji „więźniów innych narodowości”, aby ukazać, ,jakie potworne plany posiadali Niemcy dla wyniszczenia przede wszystkim narodu polskiego". W narracji kolejnej wystawy, otwartej 22 lipca 1954 r., poprzez dobór materiałów ikonograficznych i dokumentów, a także manipulacje na poziomie języka opisu, problematyka związana z eksterminacją Żydów była marginalizowana. Ofiary żydowskie przedstawiano poprzez ogólne kategorie pojęciowe, tj. jako „ludzi” czy „więźniów”, bez uwzględnienia ich przynależności etnicznej i narodowej. Dopiero następna, trzecia ekspozycja stała, przygotowana w latach 1960-1962, prezentowała wątki dotyczące Zagłady, ukazując ją jako skutek antysemickiej polityki nazistowskiej i podkreślając przynależność etniczną ofiar akcji „Reinhardt”. Zob. m.in. Robert Kuwałek, Obozy koncentracyjne i obozy zagłady jako miejsca pamięci, [w:] Następstwa zagłady Żydów. Polska 1944-2010, red. Feliks Tych, Monika Adamczyk-Garbowska, Lublin 2011, s. 494-495; Krzysztof Banach, Zagłada Żydów w świetle ekspozycji statych Państwowego Muzeum na Majdanku, „Studia Judaica” 16 (2013), nr 2, s. 117, 121-124; tenże, Działalność wystawiennicza Państwowego Muzeum na Majdanku w latach 1944-2014, „Zeszyty Majdanka” 26 (2014), s. 273; Wóycicka, Przerwana żałoba ..., s. 327; Kucia, Auschwitz jako fakt społeczny ..., s. 182183, 188; zob. też Memoriat Państwowego Muzeum na Majdanku, dotyczacy prac dokonanych i rozplanowania dalszej działalności, 3 stycznia 1945, Archiwum Państwowego Muzeum na Majdanku [dalej: APMM], Archiwum Zakładowe [dalej: AZ], sygn. I/3, k. 2, 13.

${ }^{6}$ Kuwałek, Obozy koncentracyjne..., s. 516.

7 Jest to oficjalna nazwa obozu, potocznie nazywanego obozem na Majdanku.

8 Tamże, s. 517.

${ }_{9}$ W wytycznych do planów pracy muzeów wysłanych przez Ministerstwo Kultury w dalszych latach nakazywano, by w działalności wystawienniczej i popularyzatorskiej zwracać 
Sposób prezentowania kwestii związanych z Zagładą zmieniał się w latach osiemdziesiątych i dziewięćdziesiątych XX w. wraz z zachodzącymi przemianami politycznymi. Zakres zmian i ich charakter znajdowały odzwierciedlenie w oficjalnym dyskursie historycznym, a także - choć z pewnym opóźnieniem - w edukacji oraz działalności muzeów - miejsc pamięci, w tym też $\mathrm{PMM}^{10}$. Problematykę dotyczącą eksterminacji Żydów nadal jednak traktowano instrumentalnie: proponowane ujęcia nie uwzględniały w wystarczającym stopniu perspektywy ofiar żydowskich, idealizowano obraz relacji między więźniami różnych narodowości, pomijano odrębność sytuacji więźniów żydowskich, przemilczano określone wątki, powielano stereotypy ${ }^{11}$.

W zarysowanym powyżej kontekście losy Żydów w KL Lublin mogą stanowić przedmiot badań zarówno jako kwestia historyczna, jak i obszar zagadnień związanych z kulturowym konstruowaniem obrazu przeszłości dokonującym się w określonym miejscu i czasie pod wpływem różnego rodzaju uwarunkowań. W przypadku Lublina w procesie kształtowania się lokalnej pamięci o II wojnie światowej znaczącą rolę odegrali byli więźniowie obozu na Majdanku. Jako świadkowie historii spisywali i wydawali drukiem wspomnienia okupacyjne, angażowali się w pracę edukacyjną (spotkania z młodzieżą) oraz w działalność organizacji kombatanckich czy przygotowywanie uroczystości rocznicowych. Biorąc udział w audycjach radiowych i realizacji filmów dokumentalnych, a także uczestnicząc w nagraniach wywiadów oral history, przyczyniali się do budowania i utrwalania określonego obrazu przeszłości oraz do kształtowania opinii publicznej.

W prezentowanym artykule sposoby konstruowania narracji dotyczących okupacyjnych losów Żydów w KL Lublin ukazano w odniesieniu do korpusu materiałów źródłowych, jakimi są nagrywane od 1987 r. wywiady wideo z byłymi więźniami polskimi. Szersze tło dla prowadzonych

uwagę m.in. na następujące wydarzenia: w 1978 r. - 60. rocznicę powstania Komunistycznej Partii Polski i 30. rocznicę zjednoczenia polskiego ruchu robotniczego; w 1980 r. - 100-lecie polskiego ruchu robotniczego i 110. rocznicę urodzin Włodzimierza Iljicza Lenina; w 1987 r. - 40. rocznice zjednoczenia polskiego ruchu robotniczego, brakuje natomiast jakichkolwiek zaleceń odnoszących się do kwestii związanych z upamiętnianiem Zagłady. Wytyczne Ministerstwa Kultury i Sztuki i zalecenia, 1978, 1980, 1987, APMM, AZ, sygn. I/44, k. 141, 158, 194.

${ }^{10}$ W 1983 r. po raz pierwszy na terenie PMM odbyły się uroczystości upamiętniające 40. rocznicę egzekucji Żydów w obozie 3 listopada 1943 r. APMM, Nagrania audio, sygn. VIII-151.

${ }^{11}$ Banach, Działalność..., s. 273-310. 
rozważań stanowiły opracowania historyczne, a także różnego rodzaju materiały archiwalne odnoszące się do działalności PMM. Pytania badawcze dotyczyły m.in. takich kwestii, jak: konteksty przywoływania obecności więźniów żydowskich w obozie, sposoby określania pozycji i miejsca Żydów w obozowej hierarchii, przedstawianie relacji między więźniami żydowskimi i więźniami innych narodowości oraz ukazywanie zagadnień bezpośrednio odnoszących się do Zagłady. W prowadzonych analizach uwzględniono także szerszy - społeczno-polityczny i kulturowy - kontekst powstania wywiadów wraz ze specyfiką dyskursu historycznego końca lat osiemdziesiątych XX w.

Podejmowanie - $\mathrm{z}$ wykorzystaniem źródeł oral history - tematyki odnoszącej się do działających na terenie okupowanej Polski różnego typu obozów zakłada wykraczanie poza obszar zagadnień o charakterze stricte historycznym, co wiąże się z przekraczaniem ram warsztatu badawczego historyka oraz poszukiwaniem szerszej perspektywy teoretycznej uwzględniającej metody analizowania materiałów zaczerpnięte z innych dziedzin humanistyki oraz nauk społecznych. Takie podejście ma szczególne znaczenie w sytuacji, gdy cele badawcze pracy odległe są od analiz historycznych w tradycyjnym rozumieniu i nie tyle skupiają się wokół dążenia do „obiektywnego przedstawiania faktów”, ile - jak w prezentowanym opracowaniu - ukierunkowane są na poznawanie narracyjnego obrazu przeszłości poprzez studiowanie wspomnień świadków historii. Prowadzone badania, choć w sensie historycznym odnoszą się do przeszłości, stanowią refleksję nad pamięcią czasów, w których analizowane relacje zostały nagrane. Przyjęto, że sposoby przywoływania kwestii związanych z obecnością Żydów w obozie, wraz z wszelkimi nieścisłościami i przeinaczeniami, ujmowane będą jako odzwierciedlenie wyobrażeń o przeszłości, a także przekonań i opinii narratorów, po częśsi zakorzenionych w pamięci zbiorowej o II wojnie światowej, po części - pamięć tę kształtujących.

W prowadzonych badaniach uwzględniono, za Piotrem Filipkowskim, podejście do interpretacji wywiadów nawiązujące do założeń jakościowej analizy treści odwołującej się do kilku różnych koncepcji teoretycznych ${ }^{12}$. Przedmiotem zainteresowań badawczych jest tu związane z pobytem w obozie doświadczenie polskich więźniów, ujęte w formę narracji i analizowane w kontekście zagadnień dotyczących przebywających na Majdanku Żydów. „Uważne czytanie” (słuchanie i oglądanie) wywiadów służyć ma

${ }^{12}$ Zob. m.in. Piotr Filipkowski, Historia mówiona i wojna. Doświadczenie obozu koncentracyjnego w perspektywie narracji biograficznych, Wrocław 2010, s. 12. 
rozpoznaniu, jakiego rodzaju treści odnoszące się do żydowskich więźniów pojawiają się we wspomnieniach oraz w jaki sposób są one przywoływane. Prowadzone analizy - ze względu na cele badawcze pracy - nie są ukierunkowane na weryfikowanie określonych hipotez ani na wyjaśnianie mechanizmów społecznych. Podobnie jak w przypadku badań Piotra Filipkowskiego chodzi tu o stworzenie „raportu” z ,wnikliwej lektury” wywiadów ${ }^{13}$ ujmowanych jako teksty kultury, które są zapisem indywidualnego doświadczenia, ale też materiałem odzwierciedlającym - na poziomie jawnych treści oraz ukrytych warstw przekazu - poglądy, postawy i emocje rozmówców związane z wydarzeniami z przeszłości.

\section{Losy Żydów na Majdanku: dane historyczne i stan badań}

Zagadnienia dotyczące Żydów w obozie na Majdanku są omawiane we współczesnej literaturze przedmiotu, a istniejące opracowania historyczne i popularnonaukowe oraz publikowane wspomnienia ocalałych dostarczają wielu informacji odnośnie do obozowych losów żydowskich więźniów ${ }^{14}$. Ramy tego artykułu i przyjęte cele badawcze nie pozwalają na szerszą prezentację tych zagadnień, toteż w tym miejscu jedynie szkicowo przywołane zostaną najważniejsze kwestie odnoszące się do Żydów w obozie na Majdanku, uznane za szczególnie istotne z perspektywy rozważań prowadzonych w dalszej części tekstu.

Obóz na Majdanku istniał od jesieni 1941 do 22 lipca 1944 r. W tym czasie przetrzymywano tu ogółem ok. 150 tys. więźniów różnych narodowości. Do czasu masowej egzekucji określanej kryptonimem „Erntefest”, przeprowadzonej 3 listopada 1943 r., największą grupę więźniów stanowili Żydzi (łącznie ok. 74 tys. osób), w tym przede wszystkim obywatele

13 Tamże, s. 17.

${ }^{14}$ Zob. m.in.: Marta Grudzińska, Żydzi słowaccy w obozie koncentracyjnym na Majdanku, „Studia Żydowskie. Almanach” 4 (2014), s. 53-75; Tomasz Kranz, Zagłada Żydów w obozie koncentracyjnym na Majdanku, Lublin 2010; Erntefest 3-4 listopada 1943 - zapomniany epizod Zagłady, red. Wojciech Lenarczyk, Dariusz Libionka, Lublin 2009; Akcja Reinhardt. Zagłada Żydów w Generalnym Gubernatorstwie, red. Dariusz Libionka, Warszawa 2004; Tomasz Kranz, Eksterminacja Żydów na Majdanku i rola obozu w realizacji „Akcji Reinhardt”, „Zeszyty Majdanka” 22 (2003), s. 7-55; Robert Kuwałek, Żydzi lubelscy w obozie koncentracyjnym na Majdanku, „Zeszyty Majdanka” 22 (2003), s. 77-121; tenże, Zbrodnie w Lesie Krepieckim w świetle zeznań świadków, „Zeszyty Majdanka” 21 (2001), s. 307-349; Masowe egzekucje Żydów 3 listopada 1943 r. Majdanek, Poniatowa, Trawniki, oprac. Edward Dziadosz, Lublin 1988; Tatiana Berenstein, Adam Rutkowski, Żydzi w obozie koncentracyjnym Majdanek (1941-1944), „Biuletyn ŻIH” 58 (1966), s. 3-57. 
polscy (ok. 56,5 tys. osób) oraz Żydzi z innych krajów, głównie ze Słowacji, z Protektoratu Czech i Moraw oraz III Rzeszy, a także z Grecji, Holandii i Francji (ok. 17,5 tys. osób). Drugą co do liczebności grupą więźniów byli Polacy, trzecią - obywatele ZSRR: Rosjanie, Białorusini i Ukraińcy. Nieżydowscy więźniowie z Europy Zachodniej: Włosi, Niemcy, Francuzi, Norwegowie i Holendrzy, stanowili niewielki odsetek ogółu uwięzionych ${ }^{15}$.

Transporty więźniów żydowskich przybywały na Majdanek - z różnym natężeniem - przez cały okres funkcjonowania obozu. Za Tomaszem Kranzem można wskazać następujące okresy deportacji. Pierwszy - od października 1941 do końca marca 1942 r. - kiedy to na Majdanek sprowadzono Żydów z Lublina i okolic, którzy wraz z żydowskimi jeńcami z obozu przy ulicy Lipowej oraz jeńcami sowieckimi przeniesionymi ze stalagu w Chełmie pracowali przy budowie obozu. W grudniu 1941 r. na Majdanku osadzono 150 Żydów z getta lubelskiego ${ }^{16}$. Drugi okres obejmuje marzec-czerwiec 1942 r., gdy do obozu przybywały grupy Żydów ze Słowacji, z Protektoratu Czech i Moraw, III Rzeszy oraz z gett w Lublinie i na Lubelszczyźnie. Znającym język niemiecki Żydom słowackim powierzono stanowiska funkcyjne i lepsze miejsca pracy ${ }^{17} .20$ kwietnia $1942 \mathrm{r}$. na Majdanek przyprowadzono ok. 2500-3000 osób z likwidowanego getta lubelskiego ${ }^{18}$. W trzecim okresie - między 3 lipca a grudniem 1942 r. - do obozu trafili Żydzi z getta w Lublinie i gett w dystrykcie lubelskim oraz z getta warszawskiego. Okres od 4 stycznia do marca 1943 r. charakteryzuje się napływem następnych Żydów z dystryktu lubelskiego. Dalsza faza to masowe deportacje z likwidowanych gett w Warszawie i Białymstoku trwające od kwietnia do września 1943 r. Przełomową datą w historii Żydów na Majdanku jest 3 listopada 1943 r., kiedy to dokonano największej egzekucji w historii obozów koncentracyjnych: rozstrzelano wówczas w ramach akcji „Erntefest” ok. 18 tys. Żydów z Majdanka oraz z obozów pracy i komand w Lublinie ${ }^{19}$. Z masakry ocalono ok. 300 kobiet, które zajmowały się sortowaniem odzieży po zamordowanych, oraz 300 mężczyzn, których skierowano do pracy przy paleniu ciał ofiar ekshumowanych w różnych

15 Dane liczbowe za: Kranz, Zagłada Żydów..., s. 29-30, 76.

${ }^{16}$ Kuwałek, Żydzi lubelscy..., s. 4; Marta Grudzińska, Violetta Rezler-Wasielewska, Lublin, Lipowa 7. Obóz dla Żydów - polskich jeńców wojennych (1940-1943), „Kwartalnik Historii Żydów" (2008), nr 4, s. 503, 510.

${ }^{17}$ Grudzińska, Żydzi słowaccy..., s. 56-57; taż, Dionyz Lénard. Relacja z pobytu w obozie na Majdanku (kwiecień-czerwiec 1942 roku), „Zeszyty Majdanka” 26 (2014), s. 140.

${ }_{18}$ Kuwałek, Żydzi lubelscy..., s. 13.

19 Więcej na temat tej masakry zob.: Erntefest 3-4 listopada 1943... 
miejscowościach Lubelszczyzny. Kilku Żydów ukrywających się w obozie na aryjskich papierach zabito w kolejnych dniach na skutek prowadzonych śledztw i donosów współwięźniów ${ }^{20}$. Ostatni okres deportacji Żydów przypada na czas od grudnia 1943 do lipca 1944 r., na Majdanek trafiały wówczas nieliczne grupy więźniów z innych obozów²1.

Pochodzący z różnych krajów Żydzi nie tworzyli jednolitej społeczności, jednakże - jako przedstawiciele grupy będącej ofiarą akcji „Reinhardt” znajdowali się na najniższym szczeblu hierarchii więźniarskiej. Byli traktowani w sposób szczególnie okrutny zarówno przez załogę obozową, jak i więźniów funkcyjnych ${ }^{22}$, mieli utrudniony dostęp do opieki medycznej, nie mogli otrzymywać pomocy ani ze strony instytucji charytatywnych, ani od rodzin. Jako jedyni wśród wszystkich grup więźniarskich podlegali stałym selekcjom i byli masowo mordowani. Według obliczeń Tomasza Kranza życie w obozie straciło ok. 80 tys. osób, w tym ok. 60 tys. Żydów, co stanowiło ok. $75 \%$ wszystkich ofiar ${ }^{23}$. Spośród więźniów żydowskich KL Lublin największe szanse na przetrwanie mieli ci, którym udało się zbiec lub którzy zostali deportowani do innych obozów.

W okresie powojennym badania dotyczące Żydów na Majdanku były prowadzone w bardzo ograniczonym zakresie ${ }^{24}$ - opublikowany w $1966 \mathrm{r}$.

${ }^{20}$ Wojciech Lenarczyk, ,Straszny strach”. Reakcje polskich więźniów KL Lublin na akcję „Erntefest” w świetle grypsów, [w:] Erntefest 3-4 listopada 1943..., s. 85.

${ }^{21}$ Kranz, Zagłada Żydów..., s. 21; zob. też Marta Grudzińska, Więźniowie z Majdanka deportowani do KL Plaszow w kwietniu 1944 roku, [w:] Płaszów. Odkrywanie, Kraków 2016, s. 73-96; Wojciech Lenarczyk, Obóz pracy przymusowej w Budzyniu (1942-1944), [w:] Erntefest 3-4 listopada 1943..., s. 261-286.

${ }^{22}$ Marta Grudzińska, Obraz relacji między więźniami różnych narodowości w obozie koncentracyjnym na Majdanku, „Zeszyty Majdanka” 26 (2014), s. 156.

${ }^{23}$ Kranz, Zagłada Żydów..., s. 29-30, 76.

${ }^{24}$ Jak wskazują Anna Wiśniewska i Czesław Rajca w artykule podsumowującym działalność naukową Państwowego Muzeum na Majdanku, badania dotyczące losu Żydów w obozie nie były istotnym przedmiotem zainteresowań naukowych przez wiele lat. Zgodnie z wykładnią państwową zainteresowania pracowników Muzeum skupiały się na odtwarzaniu historii Majdanka oraz na zagadnieniach związanych z szeroko rozumianą ,problematyką martyrologii Polaków”, tj. na pacyfikacjach i egzekucjach, pracy przymusowej czy przemieszczaniu ludności, zob.: Anna Wiśniewska, Czesław Rajca, Działalność naukowa Państwowego Muzeum na Majdanku, „Zeszyty Majdanka” 16 (1995), s. 63, 61. Jak wynika z analizy bibliografii publikacji pracowników Muzeum na Majdanku za okres 1944-1990, zagadnienia dotyczące Zagłady podejmował Józef Marszałek, udostępniając wyniki swoich prac w 1984 r. w dwutygodniku „Fołks Sztyme”, za: Alicja Matczuk, Tomasz Kranz, Bibliografia publikacji pracowników Państwowego Muzeum na Majdanku, Lublin 2004, s. 75. Problematyka związana z obecnością Żydów w obozie na Majdanku i w innych obozach na Lubelszczyźnie pojawiała się także sporadycznie na łamach periodyku „Zeszyty Majdanka”, wydawanego przez Muzeum od 1965 r. Żydzi wspominani są tam m.in. w kontekście losów poszczególnych grup więźniów, przy omawianiu kwestii związanych z grabieżą mienia, 
artykuł Tatiany Berenstein i Adama Rutkowskiego ${ }^{25}$, mimo że zawierał liczne nieścisłości, przez lata pozostawał głównym opracowaniem odnoszącym się do tej problematyki. W latach osiemdziesiątych obserwować można zmiany, jeśli chodzi o przedstawianie losów Żydów w czasie okupacji ${ }^{26}$, jednocześnie jednak w monografiach KL Lublin wydanych w roku 1981 i $1991^{27}$ sposoby prezentowania sytuacji więźniów w obozie pozostawały zgodne z ujęciami dominującymi w ówczesnej polityce historycznej PRL, a zatem za główną grupę osadzonych uważano Polaków, których „walka i męczeństwo" oraz heroiczne zachowanie miały być wzorem postaw dla następnych pokoleń, podczas gdy losy Żydów zazwyczaj pomijano milczeniem ${ }^{28}$.

Pod koniec XX w. problematyka żydowska znalazła szersze odzwierciedlenie w pracach badawczych pracowników PMM. Szczególną rolę należy tu przypisać Tomaszowi Kranzowi, który analizował funkcję Majdanka w nazistowskiej polityce eksterminacyjnej oraz podjął wysiłki na rzecz ustalenia danych liczbowych dotyczących więzionych i zgładzonych na

z pracą komand więźniarskich, ze sposobami ewidencji więźniów czy transportami do Majdanka i z obozu, jednakże znajdujące się tam informacje były w znaczącym stopniu zniekształcone, zob.: Edward Dziadosz, Stosunki handlowe obozu koncentracyjnego na Majdanku z firma Paula Reimanna, „Zeszyty Majdanka” 2 (1967), s. 174. Przykładem zniekształceń i manipulacji na poziomie faktograficznym mogą tu być m.in. artykuły, w których - choć wspomina się Żydów - wśród ofiar Zagłady wylicza się także jeńców radzieckich oraz polskich więźniów politycznych i dzieci z Zamojszczyzny, rzekomo mordowanych w komorach gazowych na Majdanku; zob. Czesław Madajczyk, Lubelszczyzna w polityce okupanta, „Zeszyty Majdanka” 2 (1967), s. 5-20; Adela Toniak, Korespondencja w sprawie dostawy gazu cyklonu B do obozu na Majdanku, „Zeszyty Majdanka” 2 (1967), s. 129-170.

${ }^{25}$ Berenstein, Rutkowski, Żydzi w obozie..., s. 3-57; zob. też: Józef Marszałek, Recenzja redakcyjna rozprawy T. Berenstein, A. Rutkowskiego pt. „Żydzi na Majdanku”, 1971/72, APMM, AZ, sygn. 66/15, k. 73-83.

${ }^{26}$ W tomach „Zeszytów Majdanka” z lat 1980 i 1983 znalazły się opracowania dotyczące obozu dla więźniów żydowskich w Poniatowej oraz dwa artykuły poświęcone prześladowaniom Żydów podczas okupacji w Czechach i na Słowacji, zob. Ryszard Gicewicz, Obóz pracy w Poniatowej, „Zeszyty Majdanka” 10 (1980), s. 88-104; Jerzy Tomaszewski, Poczatki prześladowania Żydów stowackich, „Zeszyty Majdanka” 11 (1983), s. 5-21; Miroslav Kryl, Deportacja więźniów teresińskiego getta do obozu koncentracyjnego na Majdanku w 1942 roku, „Zeszyty Majdanka” 11 (1983), s. 23-44. W 1988 r. ukazała się publikacja dotycząca egzekucji „Erntefest”, która była pierwszą wydaną przez Muzeum książką w całości poświęconą żydowskim więźniom, zob. Masowe egzekucje Żydów...

27 Zob. m.in. Józef Marszałek, Majdanek. Obóz koncentracyjny w Lublinie, Lublin 1981; Aleksy Bornus, Społeczność więźniów w świetle ich pamiętników, [w:] Majdanek 1941-1944, red. Tadeusz Mencel, Lublin 1991, s. 293-305; zob. też: Recenzje i uwagi do monografii „Obóz koncentracyjny na Majdanku 1941-1944”, 1979-1986, APMM, AZ, sygn. 66/64.

${ }_{28}$ Więcej na ten temat zob. Piotr Forecki, Od Shoah do strachu. Spory o polsko-żydowska przeszłość i pamięć w debatach publicznych, Poznań 2010, s. 15-22, 76-82; Kwiatkowski, Wprowadzenie..., s. 16-17; Szacka, II wojna światowa..., s. 81-132. 
Majdanku Żydów ${ }^{29}$. Duże znaczenie odegrały także badania następujących autorów: Roberta Kuwałka na temat dziejów społeczności żydowskiej na Lubelszczyźnie oraz historii obozów zagłady w Bełżcu i Sobiborze ${ }^{30}$; Dariusza Libionki o zagładzie Żydów w Generalnym Gubernatorstwie, w tym m.in. egzekucji „Erntefest”31; Wojciecha Lenarczyka odnoszące się do obozów pracy na terenie Lubelszczyzny ${ }^{32}$; Marty Grudzińskiej poświęcone m.in. losom Żydów deportowanych na Majdanek ${ }^{33}$ oraz Krzysztofa Banacha dotyczące społeczności żydowskiej Lublina przed II wojną światową i w jej trakcie ${ }^{34}$.

Jak wynika z obserwacji pracowników Muzeum, pomimo prowadzonych badań i wydawanych publikacji dotyczących Żydów w obozie na Majdanku oraz okupacyjnych losów Żydów w Lublinie i na terenie Generalnego Gubernatorstwa wiele osób spośród zwiedzających PMM uważa, że był to obóz o typowo polskim charakterze, i nie wie, jaką rolę odegrał on w procesie Zagłady. Wydaje się, że sytuację tę, pośrednio potwierdzającą

${ }^{29}$ Zob. m.in.: Kranz, Zagłada Żydów...; tenże, Egzekucja Żydów na Majdanku 3 listopada 1943 r., [w:] Erntefest 3-4 listopada 1943..., s. 25-36; tenże, Eksterminacja Żydów na Majdanku..., s. 7-55; tenże, Obóz koncentracyjny na Majdanku a „Akcja Reinhardt”, [w:] Akcja Reinhardt..., s. 233-247.

${ }^{30}$ Zob. m.in.: Robert Kuwałek, Wiesław Wysok, Lublin. Jerozolima Królestwa Polskiego, Lublin 2001; Kuwałek, Zbrodnie w Lesie Kręieckim ...; tenże, Żydzi lubelscy...; tenże, Obóz zagłady w Bełżcu, Lublin 2010; tenże, Obóz zagłady w Sobiborze w historiografii polskiej i obcej, „Zeszyty Majdanka” 21 (2001), s. 115-161; tenże, Nowe ustalenia dotyczace liczby ofiar niemieckiego obozu zagłady w Sobiborze, „Zeszyty Majdanka” 26 (2014), s. 61-125; Obóz zagłady w Bełżcu w relacjach ocalonych i zeznaniach polskich świadków, red. Robert Kuwałek, Dariusz Libionka, Lublin 2013.

${ }^{31}$ Zob. m.in.: Erntefest 3-4 listopada 1943...; Akcja Reinhardt...; Przybyli do getta... Odeszli w nieznane... Zagłada Żydów w Generalnym Gubernatorstwie, [katalog wystawy w 70. rocznicę Akcji „Reinhardt”, Państwowe Muzeum na Majdanku, prezentowanej od 2012 r. do chwili obecnej], red. Robert Kuwałek, Dariusz Libionka, Lublin 2013; Dariusz Libionka, Obozy pracy dla Żydów na Lubelszczyźnie i ich likwidacja w optyce struktur Polskiego Państwa Podziemnego, [w:] Erntefest 3-4 listopada 1943...; tenże, Zagłada Żydów w Generalnym Gubernatorstwie. Zarys problematyki, Lublin 2017.

${ }^{32}$ Wojciech Lenarczyk, Obóz pracy na Flugplatzu w Lublinie. Historia, funkcjonowanie, więźniowie, „Zeszyty Majdanka” 26 (2014), s. 61-125; tenże, Obóz pracy przymusowej w Budzyniu...; tenże, Obóz pracy przymusowej dla Żydów przy ul. Lipowej w Lublinie (1939-1943), [w:] Erntefest 3-4 listopada 1943..., s. 37-71.

${ }_{33}$ Grudzińska, Żydzi stowaccy...; taż, Dionyz Lénard..., s. 181-250; taż, Los Żydów ze Stowacji deportowanych na Majdanek, „Judaica et Holocaustica” 4 (2015), s. 33-57; taż, Więźniowie z Majdanka deportowani...; taż, Los Żydów w obozie koncentracyjnym na Majdanku, [w:] Losy Żydów z Krasnegostawu i okolic. Zbiór artykułów i scenariuszy zajęć z zakresu antydyskryminacji i edukacji o Zagładzie, red. Lena Bielska, Katarzyna Zabratańska, Lublin 2016, s. 70-80; Grudzińska, Rezler-Wasielewska, Lublin, Lipowa 7..., s. 490-514.

${ }^{34}$ Krzysztof Banach, Dzielnice Zagłady. Niemieckie getta dla Żydów w okupowanym Lublinie, Lublin 2017. 
niski poziom wiedzy o Zagładzie, można postrzegać w kontekście wieloletniego wpływu mediów i działań edukacyjnych na kształtowanie się takiego właśnie obrazu przeszłości ${ }^{35}$.

\section{Wywiady z byłymi więźniami Majdanka jako materiały źródłowe}

Trudności związane z badaniem losów żydowskich więźniów na Majdanku wynikają m.in. z faktu, iż materiały archiwalne dotyczące KL Lublin zostały w dużej mierze zniszczone przez załogę obozu tuż przed jego likwidacją. Współczesnym badaczom dostępne są szczątkowo zachowane dokumenty pochodzące $\mathrm{z}$ akt kancelarii komendantury, zawierające najczęściej dane statystyczne odnoszące się do stanów osobowych, śmiertelności w obozie czy liczebności komand, na podstawie których nie jest możliwe odtworzenie warunków życia w obozie czy relacji między więźniami. W dostępnych materiałach archiwalnych w zasadzie nie znajdują odzwierciedlenia dane o obozowych losach i eksterminacji przebywających na Majdanku Żydów (dotyczące m.in. selekcji, egzekucji czy śmierci w komorach gazowych), toteż prowadzenie badań nad tymi zagadnieniami wymaga odwołania się do materiałów nielegalnie wytworzonych przez więźniów w czasie okupacji (tajne raporty wysyłane do struktur Polskiego Państwa Podziemnego, grypsy) oraz do powstających po wojnie źródeł wywołanych (zeznania, spisane wspomnienia ${ }^{36}$, ankiety, relacje mówione audio i wideo, protokoły przesłuchań i kwestionariusze osobowe $)^{37}$.

35 Zob. m.in.: Robert Kuwałek, Byly obóz koncentracyjny na Majdanku i miejsca po obozach zagłady na Lubelszczyźnie w prasie i świadomości mieszkańców (1944-1956), [w:] Słowa w stużbie..., s. 275-292.

${ }^{36}$ Wspomnienia byłych więźniów obozu wpływały do Muzeum od 1945 r. w odpowiedzi na apele zamieszczane m.in. w prasie i radiu. Jako główny cel gromadzenia dokumentów osobistych i relacji wskazywano m.in. zbieranie informacji o obozie i życiu codziennym więźniów, dążenie do kompletowania materiałów dowodowych o zbrodniach popełnionych przez Niemców, a także nawiązywanie kontaktów z byłymi więźniami. Zob. Sprawozdanie, 1945, APMM, AZ, sygn. I/3, k. 133; zob. też m.in.: Uwaga b. więźniowie obozów koncentracyjnych, składajcie zeznania na katów obozowych, „Gazeta Robotnicza” 73 (15 marca 1947); Za zbrodnie kara, „Kurier Codzienny” 151 (6 grudnia 1945); „Głos Ludu” 32 (22 grudnia 1944); „Robotnik” 1 (5 stycznia 1945); zob. też APMM, AZ, sygn. I/3 (3 stycznia 1945), k. 28.

${ }^{37}$ Marta Grudzińska, Wstęp, [w:] Przewodnik po zbiorze relacji i pamiętników znajdujących się w zasobie Państwowego Muzeum na Majdanku, Lublin 2011, s. 9. Obecnie (wrzesień 2017 r.) zasoby Archiwum PMM zawierają 849 spisanych wspomnień byłych więźniów Majdanka, 13115 ankiet osobowych, a także 44 kwestionariusze osobowe. W wielu przypadkach do ankiet i kwestionariuszy dołączone są kilkustronicowe relacje wspomnieniowe. 
Inny rodzaj źródeł wywołanych stanowią relacje mówione rejestrowane przez pracowników PMM od 1977 r. Działania te motywowano potrzebą rejestracji głosów odchodzących świadków historii oraz koniecznością gromadzenia nagrań, które można by wykorzystać jako uzupełnienie ekspozycji muzealnej ${ }^{38}$. Obecnie (wrzesień 2017 r.) w skład zasobu archiwalnego Muzeum wchodzi ok. 500 wywiadów audio oraz ponad 500 nagrań wideo ${ }^{39}$ udzielonych przez byłych więźniów Majdanka i ich rodziny oraz mieszkańców Lublina - są to wspomnienia dotyczące okupacji niemieckiej ${ }^{40}$.

Początkowo Muzeum gromadziło wyłącznie nagrania audio. Większość rozmów z byłymi więźniami zarejestrowanych pod koniec lat siedemdziesiątych i w I połowie lat osiemdziesiątych to tradycyjne, standaryzowane wywiady z wykorzystaniem ramowego kwestionariusza, odnoszące się na poziomie treści do konkretnych zagadnień związanych z funkcjonowaniem obozu. Interlokutorzy przedstawiają okoliczności aresztowania i uwięzienia, opisują procedurę przyjęcia do obozu, warunki bytowe, charakter wykonywanej pracy i rozkład dnia, kończąc przywołaniem informacji dotyczących transportu lub zwolnienia, ewentualnie ucieczki z obozu. W wywiadach pojawiają się także informacje o różnych formach oporu i samopomocy oraz wsparcia udzielanego spoza obozu. Częste są też refleksje dotyczące życia osobistego i stanu zdrowia. W omawianym okresie metoda prowadzenia rozmów, oparta na udzielaniu przez interlokutorów odpowiedzi na ustandaryzowane pytania, stosowana była przez instytucje zajmujące się gromadzeniem wspomnień. Tego typu nagranie przypomina raczej - jak wskazuje Piotr Filipkowski - zeznanie czy zapis przesłuchania przed komisją historyczną niż rozmowę ze świadkiem historii zarejestrowaną $\mathrm{z}$ uwzględnieniem metodologii historii mówionej ${ }^{41}$.

Nagrania w technice wideo realizowane są od 1987 r., przy czym zasadnicza część zbioru powstała w latach 1987-1996 ${ }^{42}$. Wywiady te nagrywane

${ }^{38}$ Zob. m.in.: APMM, AZ, sygn. 66/86, k. 10; Marta Grudzińska, Zbiór „Nagrania audio” w zasobie Archiwum Państwowego Muzeum na Majdanku, „Zeszyty Majdanka” 25 (2011), s. 273.

${ }^{39}$ Stan inwentarzy PMM na 4 września 2017 r.

${ }_{40}$ Zob. Marta Grudzińska, Wywiady z bylymi więźniami jako nośniki pamięci o losach ludzi i historii miejsca. Historia mówiona w Archiwum Państwowego Muzeum na Majdanku, [w:] Historia mówiona $w$ świetle nauk humanistycznych, red. Joanna Szadura, Stanisława Niebrzegowska-Bartmińska, Mirosław Szumiło, Lublin 2014, s. 317-332; taż, Zbiór „Nagrania audio”..., s. 273-280; Beata Siwek-Ciupak, Kolekcja nagrań wideo z relacjami bylych więźniów Majdanka, „Zeszyty Majdanka” 24 (2008), s. 263-269.

${ }^{41}$ Zob. Filipkowski, Historia mówiona..., s. 40.

${ }^{42}$ Siwek-Ciupak, Kolekcja nagrań wideo..., s. 269. 
były według modelu, który można za Alessandrem Portellim określić jako thick dialogue - gdzie narrator konstruuje opowieść dotyczącą wybranych aspektów przeszłości w odpowiedzi na pytania badacza będące impulsem do podjęcia narracji i/lub służące uzyskaniu dodatkowych informacji i który nie jest klasycznym wywiadem narracyjnym ani też wywiadem kwestionariuszowym $^{43}$. Są to wywiady tematyczne mające charakter opowieści o doświadczeniu obozowym ${ }^{44}$. Choć relacje realizowano z wykorzystaniem ramowego kwestionariusza, służył on jedynie wskazaniu zasadniczych wątków tematycznych, jakie mają zostać poruszone. Osoba prowadząca pozwala lokutorom na swobodne konstruowanie wypowiedzi, podąża za opowieścią, zadając pytania służące rozwijaniu określonych wątków, starając się - jak się wydaje - połączyć różne strategie konstruowania rozmowy. Nagrane relacje są z jednej strony źródłem konkretnych informacji, z drugiej zaś opowieściami budowanymi przez świadków historii w procesie autorefleksji i rekonstruowania doświadczenia biograficznego ${ }^{45}$.

\section{Żydzi na Majdanku w relacjach polskich świadków - założenia metodologiczne}

Klasyfikując zasób relacji audio i wideo w zbiorach archiwalnych PMM pod kątem narodowości interlokutorów, można wskazać cztery grupy wywiadów. Pierwsza i najliczniejsza - to wspomnienia Polaków, w tym: byłych więźniów politycznych, zakładników, osób uwięzionych w wyniku łapanek, mieszkańców znajdującej się w pobliżu obozu wsi Dziesiąta czy z terenów Zamojszczyzny oraz innych osób spoza obozu, które pomagały osadzonym. Druga grupa obejmuje relacje składane przez Żydów, trzecia wspomnienia obywateli byłego ZSRR, w tym głównie Białorusinów kobiet i dzieci, a czwarta - wywiady z więźniami z Europy Zachodniej ${ }^{46}$.

${ }^{43}$ Por. Agata Stolarz, Podróż do Mezeritch. O doświadczeniu historii mówionej, „Wrocławski Rocznik Historii Mówionej” 4 (2014), s. 75.

${ }^{44}$ Za: Grudzińska, Wywiady z byłymi więźniami..., s. 317-332; zob. też: Filipkowski, Historia mówiona..., s. 29.

${ }_{5}$ Por. m.in.: Kaja Kaźmierska, Wywiad narracyjny jako jedna z metod w badaniach biograficznych, „Przegląd Socjologiczny” 53 (2004), nr 1, s. 78-79; Ingeborg Helling, Metoda badań biograficznych, [w:] Metoda biograficzna w socjologii, red. Jan Włodarek, Marek Ziółkowski, Warszawa 1990, s. 14; Filipkowski, Historia mówiona..., s. 29; Agata Stolarz, Historia mówiona w warsztacie historyka mentalności, „Pamięć i Sprawiedliwość” (2012), nr 2, s. 107-108; Marta Kurkowska-Budzan, Antykomunistyczne podziemie zbrojne na Biatostocczyźnie. Analiza wspótczesnej symbolizacji przeszłości, Kraków 2009, s. 32.

46 Grudzińska, Wywiady z bytymi więźniami..., s. 319. 
Zgodnie z przyjętymi założeniami przedmiotem analiz były wywiady z lokutorami należącymi do pierwszej grupy, a więc byłymi polskimi więźniami obozu, zarejestrowane od początku realizacji nagrań w technice wideo w PMM - tj. od 1987 do końca 1989 r., czyli do przełomu politycznego w Polsce, który przez badaczy zajmujących się problematyką pamięci i polityką historyczną jest postrzegany jako istotna cezura czasowa, jeśli chodzi o poruszanie problematyki Zagłady w dyskursie publicznym ${ }^{47}$. Nagrania te, zrealizowane w stosunkowo krótkim czasie przez Marię Brzezińską, stanowią zwartą i spójną grupę źródeł ${ }^{48}$. Po przeprowadzeniu wstępnych analiz - spośród 67 tworzących tę grupę relacji do dalszych badań wybrano 41 wywiadów (łącznie niemal 42 godziny). Zasadniczym kryterium doboru była charakterystyka postaci narratora związana z narodowością (Polacy w sensie etnicznym) oraz wiekiem (dorośli w czasie pobytu w obozie $)^{49}$. W siedmiu spośród 41 rozmów nie pojawiają się żadne wzmianki o Żydach ${ }^{50}$, toteż do dalszych analiz pozostawiono 34 relacje $^{51}$.

47 Zob. m.in.: Kucia, Auschwitz jako fakt społeczny..., s. 59, 204, 206, 252; Steinlauf, Pamięć nieprzyswojona ..., s, 127-136; Krystyna Kersten, Polacy, Żydzi, komunizm. Anatomia pótprawd 1939-1968, Warszawa 1992, s. 173; Bartosz Korzeniowski, Przemiany obrazu drugiej wojny światowej w polskich muzeach po roku 1989, [w:] Druga wojna światowa w pamięci kulturowej w Polsce $i$ w Niemczech 70 lat później (1945-2015), red. Jerzy Kałążny, Amelia Korzeniewska, Bartosz Korzeniewski, Gdańsk 2015, s. 105-134.

${ }_{48}$ Wywiady te przechowywane są w PMM - zob. APMM, Zbiór nagrań audiowizualnych, sygn. XXII, Nagrania: 1-67. W niniejszym artykule wywiady zostały zanonimizowane. Maria Brzezińska, reporterka Radia Lublin, była wówczas zatrudniona w Muzeum, pracując przy projekcie nagrywania relacji z byłymi więźniami.

${ }_{49}$ Kryterium narodowości (etniczności) wynika z przyjętych założeń prowadzonych badań, tj. z dążenia do analizowania sposobów, w jakich polscy więźniowie konstruują opowieści dotyczące Żydów w obozie. Wybór relacji dorosłych osadzonych z pominięciem osób, które przebywały na Majdanku jako dzieci, wynikał z przyjęcia założenia, że wiedza i rozumienie obozowej rzeczywistości były u dorosłych pełniejsze oraz że relacje te w większym stopniu opierają się na osobistych wspomnieniach z czasów okupacji, a w mniejszym - na wiedzy nabytej w okresie powojennym. Z grupy 67 wywiadów wyłączono: dziewięć nagrań z osobami, które nie były więźniami Majdanka, lecz innych obozów i więzień lub udzielały pomocy przetrzymywanym na Majdanku (APMM, Zbiór nagrań audiowizualnych, sygn. XXII, Nagrania: 10, 19, 25, 34, 47, 59, 64, 65, 67), pięć relacji więźniów innych narodowości (tamże, Nagrania: 18, 51, 54, 57, 58) i jednego dziecka (tamże, Nagranie 7) oraz 11 nagrań okolicznościowych (tamże, Nagrania: 22, 23, 27, 28, 29, 31, 44, 45, 52, 56, 62).

${ }^{50}$ Tamże, Nagrania: 11, 15, 17, 37, 38, 43, 61.

51 Wśród 34 nagrań znajduje się 30 wywiadów z pojedynczymi osobami, są tam dwa wywiady, w których udział biorą pary małżeńskie, oraz dwa wywiady grupowe (powyżej 10 osób), stąd liczba nagrań różna jest od liczby rozmówców. Większość interlokutorów (29 osób) to więźniowie polityczni osadzeni na Majdanku przez najdłuższy okres i często pełniący w obozie rolę więźniów funkcyjnych. Trzy osoby to zakładnicy przetrzymywani do trzech miesięcy, dwie dalsze to wysiedleńcy z Zamojszczyzny pozostający na Majdanku do dwóch miesięcy oraz trzy osoby ujęte w łapankach, przebywające w obozie nie dłużej niż 30 dni. Wszyscy interlokutorzy zostali wliczeni w poczet więźniów dorosłych (najmłodszy 
Badania prowadzone były z wykorzystaniem transkrypcji nagrań wideo, w szczególności tych fragmentów wypowiedzi, w których rozmówcy odnosili się w sposób bezpośredni lub pośredni ${ }^{52}$ do losu Żydów na Majdanku. Po przeprowadzeniu wstępnej analizy materiału wyróżnione zostały główne wątki i motywy odnoszące się do Żydów w obozie. Następnie na potrzeby dalszych rozważań wyodrębniono cztery rodzaje dyskursu, tj. konwencji opowiadania przez polskich więźniów o Żydach na Majdanku, odzwierciedlających złożony układ myśli, poglądów i przekonań, którym odpowiadają określone wyobrażenia i konstrukty kulturowe: dyskurs nieobecności, dyskurs odmienności, różnicy i stereotypowych wyobrażeń, dyskurs współczucia, przyjaźni i współdziałania oraz dyskurs traumatyczny ${ }^{53}$.

Choć wyodrębnione na gruncie teoretycznym, różne typy dyskursu łączą się i nakładają się na siebie w relacjach świadków. Prezentowany układ zagadnień z jednej strony wynika $\mathrm{z}$ dążenia do porządkowania zgromadzonego materiału według założeń przyjętych w trakcie wstępnych analiz, z drugiej zaś z potrzeby rekonstruowania porządku opowieści o obozowych doświadczeniach, którego źródłem jest sposób budowania obrazu życia w obozie przez samych narratorów.

\section{Dyskurs nieobecności}

Dyskurs nieobecności zauważyć można w tych relacjach byłych polskich więźniów Majdanka, w których wspomnienia dotyczące Żydów w obozie w ogóle się nie pojawiają, oraz w tych, gdzie przy okazji omawiania innych zagadnień znaleźć można zaledwie pojedyncze zdania odnoszące się do więźniów żydowskich. Wzmianki te dotyczą m.in. obecności w obozie lekarzy czy fryzjerów żydowskich, handlu wymiennego bądź też otrzymywania przez

w chwili osadzenia na Majdanku miał 16 lat). Wśród analizowanych relacji dominują wypowiedzi mężczyzn (29).

${ }^{52} \mathrm{Za}$ „pośrednie” odniesienia do losów Żydów uznane zostały tu wypowiedzi, w których lokutorzy wspominają wydarzenia dotyczące Żydów (np. mówiąc o sposobach uśmiercania w obozie), jednakże nie zaznaczają, że wypowiedź odnosi się do losów więźniów żydowskich, tak iż osoba nieznająca dziejów obozu i oglądająca relację wideo (lub czytająca transkrypcję) może nie być w stanie poprawnie zrozumieć znaczenia i sensu wspominanych wydarzeń.

${ }^{53}$ Ujęcie to nawiązuje do prac Lawrence'a L. Langera analizującego wywiady z Żydami ocalałymi z Holokaustu. Odwołując się do korpusu relacji wideo nagranych z Żydami - byłymi więźniami obozów, pochodzących z działającego od 1982 r. Fortunoff Video Archive for Holocaust Testimonies przy Uniwersytecie Yale w New Haven, autor wyodrębnia i analizuje różne typy pamięci o Zagładzie i jej pokoleniowego przekazywania; zob. Lawrence L. Langer, Świadectwa Zagłady. Wrumowisku pamięci, tłum. Marcin Szuster, Warszawa 2015. 
polskich więźniów numerów ${ }^{54}$ lub odzieży po zamordowanych Żydach. W części analizowanych wywiadów wzmianki tego rodzaju są jedynymi wspomnieniami dotyczącymi Żydów na Majdanku:

Na trzecim polu po prawej stronie w baraku numer dwanaście mieścił się rewir, w którym pracował doktór Klonowski, więzień, i drugi więzień - doktór Goldberg Żyd. [A.S.]

Po kilku dniach przyszli Żydzi czechosłowaccy z męskiego pola i oszklili nam okna. [H.K.]

Wykąpali nas, jakieś dali takie ubranie żydowskie, że młodszym kobietom dali sukienki. [M.K.]

Dali każdemu numer na nitce. Ja otrzymałem numer 3083. Był to numer po Żydzie. Jakimś Żydzie... [H.N.]

Przed łaźnią było kilku fryzjerów, to byli Żydzi, narodowości żydowskiej, bo Polaków wtenczas było jeszcze bardzo mało... którzy golili nam włosy, ale to było takie golenie... udawanie, że to się włosy strzyże, goli... [W.S.]

W nielicznych relacjach pojawiają się konkretne, szczegółowe informacje dotyczące żydowskich więźniów, pozwalające wnioskować na przykład o składzie narodowościowym obozu:

Było nas w tym baraku, w [baraku nr] 12, na I polu, 150 Żydów i 34 Polaków. [W.S.]

Mieszkańcy tego bloku to przeważnie byli Żydzi; część, tak w granicach 1/3, stanowili Polacy, kilkunastu Ukraińców, a przeważnie, jak mówię, byli to Żydzi w różnym wieku. [A.G.]

W części wywiadów pojawiają się też wzmianki o transportach ludności żydowskiej przywożonej na Majdanek z gett w Warszawie, Białymstoku i Lublinie oraz o transportach ewakuacyjnych z KL Lublin w 1944 r. Niektórym lokutorom wspomnienia te służą chronologicznemu porządkowaniu opowieści biograficznej o pobycie w obozie, będąc niejednokrotnie punktem odniesienia do przywoływania szczególnych doświadczeń osobistych, np. choroby, początku pracy w nowym komandzie itd.:

W międzyczasie zaczął się ruch duży w obozie, bo zaczęły przychodzić transporty czeskich Żydów, słowackich Żydów. No to wtedy już zaczęło się, zaczął się organizować obóz. [R.S.]

Krótko po tym [tj. po wyzdrowieniu narratora z tyfusu wiosną 1943 r.] nadeszły olbrzymie transporty Żydów z getta warszawskiego. [A.S.]

${ }^{54} \mathrm{Na}$ Majdanku nie było numeracji ciągłej. Jeśli więzień umarł, zbiegł lub został przeniesiony do innego obozu, jego numer trafiał do nowo przybyłych. Tym samym zdarzało się, że jeden numer był przypisany kilku osobom w różnym czasie. 
Tam z okien baraku [dla rekonwalescentów] widziałem [...] przychodzące transporty Żydów z getta warszawskiego po stłumieniu powstania w getcie. [J.M.]

W drugiej połowie kwietnia [19]43 roku - transport do Ravensbrück [...] Do Oświęcimia pojechały Żydówki i pomoc sanitarna, pielęgniarki. [M.W.]

W tej grupie relacji pojawiają się także wzmianki o żydowskich więźniach w kontekście kontaktów mających „handlowy” charakter, jak np. pozyskiwanie odzieży w zamian za produkty żywnościowe, a także inne formy wymiany:

[Narrator wspomina treść grypsu] udało mi się kupić, mam wrażenie, dobre rękawiczki dla ciebie. [...] Z Żydami była wymiana na chleb. [M.G.]

Odwołując się do obrazu Majdanka kreowanego w tej grupie relacji, można stwierdzić, że w ich świetle Żydzi, którzy aż do listopada 1943 r. tworzyli największą grupą etniczną w społeczności więźniarskiej, we wspomnieniach części polskich współwięźniów pozostają niemal niewidoczni. Może to wynikać m.in. z faktu separowania tej grupy od pozostałych więźniów przez załogę obozową. Kilku lokutorów wskazuje w wywiadach, że kontakty z więźniami żydowskimi były w obozie zabronione i surowo karane:

Jak ja usiłowałam [jakiś] kontakt nawiązać - nie wychodziło, bo [...] część na tych męskich polach to byli Żydzi słowaccy, tu byli Żydzi słowaccy. I oni nam przywozili jedzenie. To z nimi nie wolno było rozmawiać, bo z kolei też ich gestapowiec pilnował, ale czasami się coś udało. [J.B.]

Jeden z byłych więźniów wspomina nie tylko dystans wynikający z przestrzegania reguł narzuconych przez reżim obozowy, ale też brak możliwości porozumienia się z więźniami żydowskimi ze względu na odrębność językową:

[...] myśmy obserwowali to wyniszczenie tych ludzi, ich takie odrętwienie, bo właściwie nie wolno się było z nimi porozumiewać, ani oni z nami, ani my, to było wszystko zabronione. Ale widzieliśmy, że też nie zawsze mówili po polsku; oni mówili między sobą po żydowsku i ja nawet nie jestem przekonany, że to byli polscy Żydzi, kontaktu myśmy z nimi żadnego nie mieli. [Z.Ć.]

Jednocześnie jednak można znaleźć wypowiedzi, w których wyrażane jest zainteresowanie losem żydowskich współwięźniów:

Okna pralni były zamalowane białą farbą, żebyśmy nie musiały, nie mogły podpatrywać, co się tam dzieje. Ale pamiętam, że gdy z nami pracowała taka mała 
Aufzjerka $^{55}$, taka czarna myszka, to ona sama zdrapywała tą farbę i sama podpatrywała, co się tam dzieje. No, naturalnie, za jej przykładem i my wyglądałyśmy. Tak że widziałyśmy kilka makabrycznych scen. [H.B.]

Uprzednio zwołano nas wszystkich na apel, obowiązkowy tak zwany, ale musiałyśmy się zbliżyć do szubienicy i otoczyć tę szubienicę. Ja, jako młoda osoba, byłam też ciekawa. Niektóre panie nie chciały tego widzieć. Starsze więźniarki z doświadczeniem szły jak najdalej. Ale ja się nie wycofywałam z tych rzędów, które były bliżej. I zobaczyłam dokładnie to wszystko [tj. egzekucję żydowskiej więźniarki]. [H.B.-K.]

Powód pomijania lub marginalizowania w wielu spośród analizowanych relacji informacji dotyczących Żydów może wynikać także ze sposobu realizacji wywiadów. Z uwagi na to, że zarejestrowane rozmowy są stosunkowo krótkie (trwają średnio około godziny), można przypuszczać, iż udzielając wywiadów, lokutorzy skupiali się na własnych doświadczeniach związanych z pobytem w obozie oraz przedstawiali wydarzenia i kwestie, które uznali za najważniejsze dla swojej biografii. Można jednak również przypuszczać, że część narratorów nie wspomina (lub sporadycznie wspomina) o żydowskich współwięźniach, ponieważ powiela obowiązujący w okresie powojennym schemat konstruowania narracji o II wojnie światowej zakładający eliminowanie $\mathrm{z}$ dyskursu historycznego określonych wątków, w tym zagadnień odnoszących się do Żydów ${ }^{56}$.

Wydaje się, że można tu obserwować swoiste „sprzężenie zwrotne”: pomijanie, marginalizowanie bądź zniekształcanie przez część powojennych historyków kwestii związanych z obecnością w KL Lublin żydowskich więźniów połączone z pomijaniem i/lub autocenzurowaniem relacji tworzonych przez tę grupę przez lata wzmacniało martyrologiczną, heroiczną i polonocentryczną wykładnię dziejów obozu. Konstruowana w ten sposób narracja o przeszłości znajdowała swoje odzwierciedlenie w ekspozycjach muzealnych, będących najważniejszą formą przekazu i narzędziem edukacji, jakim posługiwało się $\mathrm{PMM}^{57}$. Uproszczony obraz obozowej rzeczywistości, (re)konstruowany niemal wyłącznie na podstawie wspomnień polskich więźniów i pomijający perspektywę żydowską (a także perspektywę więźniów innych narodowości), przez lata przedstawiany był jako pełen i całościowy, co stało się źródłem znaczących zniekształceń i przekłamań w sferze pamięci zbiorowej (społecznej, kulturowej), wpływając - jak należy przypuszczać - także na kształtowanie narracji o pobycie

55 Aufzjerka, Ausjerka (niem. Aufseherin) - nadzorczyni.

${ }_{56}$ Zob. m.in. Kuwałek, Obozy koncentracyjne..., s. 493-525; Banach, Zagłada Żydów...

57 Tamże. 
w obozie przez byłych więźniów. Sytuacja ta znalazła odzwierciedlenie w tworzonych przez nich tekstach wspomnieniowych, a także w wywiadach nagrywanych przez Marię Brzezińską.

\section{Dyskurs odmienności, różnicy i stereotypowych wyobrażeń}

Dyskurs odmienności, różnicy i stereotypowych wyobrażeń przejawia się we wspomnieniach odnoszących się do kilku różnych wątków, wśród których można wskazać kwestie dotyczące wyglądu, języka i zachowania Żydów w obozie, w tym także wypowiedzi świadczące o kulturowym zróżnicowaniu i antagonizmach między Żydami pochodzącymi z różnych krajów. Jeden z tematów dotyczy odrębności więźniów żydowskich, opisywanej w kategoriach odwołujących się do wizerunku (uroda kobiet) i ubioru (opaski na ubraniach cywilnych z getta, żółte trójkąty w obozie):

[...] patrzymy, a coś na śniegu posuwa się w naszą stronę [...] Bliżej patrzymy, a to wózek ciągniony przez ludzi. Ludzi szkieletów, w pasiakach, ci ludzie mają takie gwiazdy, żółto-czarne syjońskie gwiazdy. Jak się okazało - to Żydzi. [E.W.]

Greczynki [greckie Żydówki] ostrzyżone [...] do skóry, pracowały [...] [na] zbiorniczku, takiej tej beczce, którą wywożono [...] fekalia z tych latryn. To było niesamowite, szokujący widok. Młode, piękne dziewczyny, bo to widać po rysach, brunetki, włosy czarne, mimo że ostrzyżone, niechlujne, przecież to wszystko, przecież te fekalia po nich ściekały, przecież one przy pomocy wiaderek to wlewały. [E.S.]

[Wśród Żydów belgijskich] była piękna Żydówka, miała olbrzymie, długie włosy, takie powyżej kolan. Czarne. [H.B.]

Piękne byli [żydowskie kobiety]. Jakiś to kwiat był... kwiat narodu żydowskiego. [K.W.]

W kilku relacjach pojawia się także motyw społecznego i kulturowego zróżnicowania w grupie więźniów żydowskich: podkreślane są antagonizmy między Żydami polskimi a Żydami, którzy trafiali na Majdanek z krajów Europy Zachodniej. Kilku narratorów mówi wprost o wzajemnej niechęci między Żydami z różnych krajów:

Na pierwsze pole zaczęły przychodzić transporty rozmaitych Żydów: Polaków, rozmaitych tam [...] ze Słowacji, [...] z Niemców. Jeszcze jedno, co narzuciło mi się, że niemieccy Żydzi [...] na Żydów polskich patrzyli [...] z odrazą, z odrazą, [...] z wyższością. [...] Naturalnie, po tym wiadomy los spotkał wszystkich jednakowy. I berlińskich, i polskich, i francuskich, i tych. [J.K.]

Zwalczali [się] Żydzi - słowaccy nienawidzili [się] z polskimi. To było coś niewiarygodnego. Jak oni, ci słowaccy Żydzi, to byli ludzie bogaci, raczej kulturalni, a nasza to była biedota, tak przecież ich... tak bili, jak... jak... jak Niemcy. [E.S.] 
W części relacji pojawiają się odniesienia do specyfiki sytuacji Żydów w obozie w stosunku do pozostałych więźniów, opisywanej czasem w kategoriach bliskości i wspólnoty losów [„nasi współwięźniowie Żydzi”, „oni cierpieli tak samo jak my"], choć częściej jednak w kategoriach różnicy i odmienności wyrażanych jako opozycyjne rozróżnienie: „my”/,oni”, „my”/,Żydzi”, „więźniowie”/,Żydzi”, „Polacy”/,Żydzi”:

[o egzekucji 3 listopada] akcja skierowana była przeciwko nam albo przeciwko Żydom. [J.M.]

Ich [Żydów] [Niemcy] traktowali po prostu gorzej niż nas. [H.N.]

I wtedy ona [Polka - kobieta z dzielnicy Dziesiąta] zobaczyła, że biją tam kogoś, któregoś z mężczyzn czy którąś z kobiet. I ona zaczęła płakać i mówi: „To was tutaj tak strasznie biją?". Nawet nie wiem, skąd mi ta myśl przyszła do głowy. Ja mówię: „Nie, nas nie. Tylko Żydów”. [H.B.]

[Żydzi], którzy przyszli do nas, którzy byli pierwszymi kolegami, którzy nas na Majdanku przywitali, że my jesteśmy Polakami, że my jesteśmy więźniami politycznymi, że w stosunku do nas Niemcy zachowywać się tak nie będą jak w stosunku do Żydów. [J.M.]

W kontekście omawiania wspólnoty bądź odmienności losów Polaków i Żydów na Majdanku przywoływane są w wywiadach różnice, jeśli chodzi o stosunek do własnego losu, gdzie Polacy przedstawiają siebie jako skłonnych do przyjmowania bohaterskiej postawy [„oni” poszli na rzeź / „my” chcieliśmy zginąć w walce]:

[O egzekucji 3 listopada] Oni [Żydzi] poszli bardzo biernie. A myśmy natychmiast uzbroili się w cokolwiek, co było namiastką broni. Pilniki, noże kuchenne, nawet z tej, z tej straży pożarnej jakieś kilofy. Oczywiście to było śmieszne. Po prostu myśmy mieli świadomość, że zginiemy, ale [...] chcieliśmy zginąć w walce. [A.S. $]^{58}$

Przed naszymi oczyma [...] przesuwały się te kolumny tych..., pędzone... tych Żydów, których prowadzili tam z... z... obozów, z lubelskiego, tam gdzieś z różnej, z rozmaitych dzielnic [...]. No więc wszystkich tych zapędzili tam i... [...] Myśmy sobie właściwie rozważali [...], dlaczego ci ludzie pozwolili się w ten sposób pędzić. Chyba sądzili, że [...] nie na zagładę. Bo było ich tylu, że gdyby rzucili się, to [...] część [...] uratowałaby się... [J.K.]

${ }^{58}$ Po egzekucji 3 listopada 1943 r. współpracujący już wcześniej z AK polscy więźniowie polityczni planowali przygotowanie masowej ucieczki osadzonych. Plany te jednak nigdy nie zostały zrealizowane. Nie doszło także do skutku - wielokrotnie omawiane w tajnej korespondencji z komórkami AK - odbicie transportów ewakuacyjnych z polskimi więźniami politycznymi. Zob. Józef Marszałek, Konspiracja w obozie, [w:] Majdanek 1941-1944..., s. 363-365; Lenarczyk, „, Straszny strach”..., s. 92-96. 
Widziałem tą Żydówkę, która za Niemcem szła z pierwszego pola na rozstrzał. [...] Szła za nim trzy metry [...] nie mogłem się nadziwić, bo widać była zdrowa kobieta, że przecież ręką by go zmiotła [...] a ona szła bez oporu, bez, mimo że wiedziała, gdzie idzie. [E.S.]

Przywoływanie motywów związanych z oceną zachowania Żydów, w tym wątek „bierności” wobec Zagłady, silnie obecny w powojennych narracjach także w Europie Zachodniej, można postrzegać tu także jako formę „emocjonalnej ucieczki” narratorów od poczucia bezradności i traumy związanej z doświadczeniem listopadowej egzekucji. Odwołanie się do stereotypowych wyobrażeń dotyczących postaw więźniów żydowskich (lęk, uległość, bierność, postawa pasywna) połączone z rozwijaniem wizji dotyczących możliwości wzniecenia buntu oraz wypowiedziami wskazującymi na przekonanie o odmiennych postawach i zachowaniach więźniów polskich (gotowość do walki, chęć poniesienia śmierci w walce) może tu służyć odwróceniu uwagi od istoty dramatycznych wydarzeń, kierując ją w stronę pozytywnych wyobrażeń o własnym heroizmie i odwadze. Zdaje się, że tego rodzaju opisy i sposoby interpretowania sytuacji ofiar Zagłady, prezentowane przez polskich świadków, upraszczają obraz wydarzeń.

\section{Dyskurs współczucia, przyjaźni i współdziałania}

Dyskurs współczucia, przyjaźni i współdziałania reprezentują opowieści mówiące o pomocy i współpracy między narratorami i żydowskimi współwięźniami. Lokutorzy przywołują wspomnienia odnoszące się na przykład do ukrywania Żydów podczas selekcji, ocalenia żydowskiego noworodka ${ }^{59}$ czy dzielenia się jedzeniem:

[...] dzięki temu, że się tu coś usłyszało, tam coś usłyszało... o tych selekcjach, na ogół też byłyśmy na to przygotowane i wtedy postępowanie było, właściwie tylko... właściwie jedyna możliwość była: te najciężej chore wyrzucało się z rewiru na pole, na macierzysty blok. A jak niebezpieczeństwo mijało, to się je z powrotem przyjmowało. Tego Niemcy nie byli w stanie skontrolować. Tak że to się na ogół udawało. [J.W.]

${ }^{59}$ Dziecko ukrywano w obozie od 24 grudnia 1943 r. aż do transportu ewakuacyjnego do KL Auschwitz-Birkenau 13 kwietnia 1944 r. Dwa dni po przybyciu do KL Auschwitz-Birkenau, tj. 18 kwietnia 1944 r., kobiety żydowskie z dziećmi uśmiercono w komorze gazowej. Zofia Murawska, Kobiety w obozie koncentracyjnym na Majdanku, „Zeszyty Majdanka” 4 (1969), s. 164. 
Jedna z rozmówczyń zwraca uwagę na dylematy moralne przeżywane przez polskie więźniarki pracujące $\mathrm{w}$ szpitalu obozowym oraz na to, iż miały one świadomość, że ratowanie czy ukrywanie Żydów służyło jedynie chwilowemu przedłużeniu ich życia:

Urodziło się dziecko [żydowskie]. Urodziło się w ambulatorium. Nie odebrano go tej matce. Od razu i koleżanki z bloku, na którym pracowała pani Wanda Ossowska, one postanowiły spróbować to dziecko uratować. Nic nikomu nie mówiąc, przetrzymywały to dziecko na stryszku w bloku. [...] No i ono nam się tam chowało ładnych parę miesięcy i dopiero później, jak trzeba było z Majdanka wyjeżdżać, to się okazało, ku ogromnemu zdziwieniu Niemców, że jest jeden więzień więcej w naszym stanie liczebnym. Ale później to dziecko w Oświęcimiu chyba razem z matką zginęło. [...] Wszystko, co się działo, to też na dobrą sprawę nie było wiadomo, czy to dobrze, że się go uratowało. Może lepiej by było, żeby ono jako zupełne, kilkugodzinne niemowlę przestało żyć. Wie pani, to strasznie trudno jest... trudno jest... [J.W.]

No więc... no to, co można było robić, oczywiście robiło się, żeby ją [Niusię Marder] uratować, i to się udało, ona przeżyła te oba tyfusy. Tylko niestety później, 3 listopada, w dniu pogromu Żydów, ona została oczywiście zabita. [J.W.]

W tej grupie relacji sytuacja Żydów w obozie jest opisywana jako gorsza niż pozostałych osadzonych, pojawiają się opisy sytuacji, w których więźniowie żydowscy przedstawiani są jako bardziej narażeni na szykany i śmierć, pozbawieni dostępu do opieki medycznej, obarczani najtrudniejszą pracą:

Widziałam, jak on [szef krematorium] ciągle pejczem bije tych biednych więźniów, którzy byli zatrudnieni w krematorium, a którzy po trzech, czterech tygodniach byli likwidowani, żeby nie było świadków. I nowi, ciągle nowi. [E.W.]

Oni [Żydzi] przeważnie byli bici za każde przewinienie, także błahe, czy źle zrobił, czy zakończył. [...] Ich traktowali po prostu gorzej niż nas. [H.N.]

Na trzecim polu [...] była szubienica. [...] Pewnego dnia [...] poszła ogromna zlewa na Majdanku w czasie pracy więźniów. Dużo więźniów uciekało, chowało się przed tym deszczem. Bo przecież nie wysuszy się nigdzie. I [...] Thumann czy któryś z esesmanów znalazł kilku Żydów, którzy się schowali przed deszczem. [...] Po wieczornym apelu kazano nam się ustawić w czworobok obok tej szubienicy i oznajmiono nam, że za to, że ukrywali się i nie pracowali więźniowie w czasie deszczu, zostaną skazani na śmierć. I wieszano wtedy trzech obywateli żydowskich za to właśnie. [A.G. $]^{60}$

Żydówki pracowały na tym Gärtnerei ${ }^{61}$. [...] Pracowałam ja wtedy jako sprzątaczka w tym [baraku]. Aufzjerka przyszła rano i powiedziała, że nie wolno myć

${ }^{60}$ W KL Lublin wieszano więźniów przyłapanych na próbie ucieczki lub - jak w tym przypadku - jedynie o nią posądzanych.

${ }^{61}$ Gärtnerei (niem. 'zakład ogrodniczy'), tu: część terenu obozu przeznaczona pod uprawę warzyw. 
się Żydówkom, tylko wolno myć się Aryjkom. [...] Było pod wieczór, koniec dnia, one pracowały, przyszły zmęczone, spocone [...], spracowane [...] Pytają się te Żydówki, czy się mogą umyć, a ja mówię: „Prędko się macie umyć, ale prędko, żeby nas nie złapali”. One się zdążyły umyć i na koniec ich mycia wpadła Aufzjerka, potłukła mnie niesamowicie, powiedziała, żeby [...] nie pozwolić [się] myć Żydówkom. [J.B.]

W niektórych fragmentach wypowiedzi pojawia się współczucie dla więźniów żydowskich [,„biedni więźniowie”, „nieszczęsne Żydówki”, „nieszczęsne istoty"], wyrażany jest żal i poczucie bezsilności wobec cierpienia innych, opisywane są próby niesienia pomocy:

Ale to, na co musiałyśmy patrzeć: [...] na dzieci Zamojszczyzny, na tych chłopów, Żydów z getta: najpierw białostockie, potem warszawskie. Oczywiście jako sanitarna kolumna, jak to się mówi, w pierwszej linii przy tych transportach mimo początkowo zakazów izolacji, to się nie liczyło, myśmy tam szły i znowu całkowita bezsilność. Ranni, którzy byli natychmiast narażeni na to, że... że w tej chwili zostaną zagazowani, a którym nie można nic pomóc. [W.G.-N.]

Mnie wywieźli do Ravensbrück, no a właśnie te Żydówki, te nieszczęsne, ocalone wtedy z tej strasznej kaźni trzeciego listopada właśnie [19]43 roku, zostały wywiezione do Oświęcimia. [H.K.]

W tym czasie, akurat po powstaniu w getcie warszawskim, przyjeżdżały do nas ogromne transporty Żydów i Żydówek. [...] Na nasze pole przyjechało chyba $\mathrm{z}$ dziesięć tysięcy. No, były to nieszczęsne istoty. [H.K.]

W tej grupie relacji przywoływana jest także odrębność statusu i sytuacji Żydów w obozie, która - w wielu przypadkach - była punktem wyjścia do podejmowania przez narratorów działań ukierunkowanych na pomoc dla żydowskich współwięźniów (wymiana informacji, udostępnianie leków itd.). Jedna z narratorek opowiada o współpracy między Polkami pracującymi w pralni a słowackim Żydem - lekarzem, który dostarczał informacje oraz leki do podręcznej apteczki w zamian za stworzenie warunków do potajemnego udzielania pomocy lekarskiej żydowskim osadzonym:

Za jakiś czas przyszedł [do pralni] ten lekarz Słowak - Paweł. ${ }^{62}[\ldots]$ Mówi, że on uzupełni [...] apteczkę [znajdującą się w pralni] wszystkimi potrzebnymi maściami i lekami, i tak dalej, pod warunkiem, że będą z tej apteczki mogli korzystać Żydzi i Żydówki. Bo na rewir [tj. do obozowego szpitala] Żydom wstęp był wzbro-

${ }^{62}$ Być może chodzi tu o Ernesta Landensmanna - lekarza, Żyda ze Słowacji, który popełnił samobójstwo w dniu egzekucji 3 listopada 1943 r. Zob. Grudzińska, Los Żydów..., s. 56; Marta Grudzińska, Maria Ciesielska, Lekarze w pasiakach. Stużba medyczna na Majdanku. Wystawa internetowa, http://lekarze-w-pasiakach.majdanek.eu/pl/lekarze-lekarze-stomatolodzy-i-studenci-medycyny-na-majdanku/ [dostęp: 2 października 2017]. 
niony. Nie mogli korzystać z żadnej opieki lekarskiej. No, zgodziłam się chętnie, bo przecież nie byłam specjalnie nastawiona przeciwko Żydom. Tak samo to byli ludzie, którzy cierpieli na równi z nami, a nawet może i gorzej. I odtąd zaczęła się pomoc taka cicha. [...] Przychodząc z tymi fartuchami [do pralni], równocześnie robił takie drobne zabiegi chirurgiczne. Na przykład przecięcie wrzodów. [H.B.]

W tej grupie relacji pojawiają się także wspomnienia dotyczące pomocy i wsparcia, jakiej narratorzy doświadczyli ze strony Żydów:

Wszystkie funkcje, jak blokowego [...], zastępca tego blokowego, to byli Żydzi z tej Słowacji. [...] Dałem [blokszrajberowi] ${ }^{63}$ chyba paczkę papierosów, to był Żyd. I oni zupełnie zaczęli inaczej, inaczej patrzeć na mnie. Już jak gdybym był w ich grupie. Czuli, że mogę im tam coś przynieść. [...] Spośród Żydów, tam byli ci słowaccy, był jeden taki dosyć młody, no starszy ode mnie, odchodził do szpitala i wręczył mi sto dolarów. Powiedział tak: jeśli wróci, to mu oddam; jeśli nie wróci, to sobie zatrzymam. [Z.B.]

Później [...] poznałem tych, co tam [w kantynie] z nimi pracowałem. Tam było chyba pięciu Polaków i czterech Żydów ze Słowacji, wszyscy umieli po niemiecku. Pytają się, czy ja umiem; no, ja mówię, że nie umiem; no ale jakoś, no nie wiem, jak oni to załatwili, jakoś ktoś się tam za mną wstawił, żeby mnie tam zatrzymali, a ja tam przychodziłem do pracy. [Z.B.]

Mówiąc o wzajemnej pomocy, lokutorzy podkreślają też różnice w traktowaniu Polaków i Żydów przez załogę obozową, wskazując przy tym, że za udzielanie pomocy Polakom Żydzi ponosili poważne konsekwencje groziła im na przykład utrata funkcji:

No i niestety, za którymś razem spotkał go znowu Benden i karą za to była dyskwalifikacja jego. Nie pozwolił mu pracować na rewirze jako lekarzowi. [H.B.]

\section{Dyskurs traumatyczny}

Dyskurs traumy jest szeroko reprezentowany w analizowanych relacjach. Żydowscy współwięźniowie przywoływani są przez wielu narratorów w kontekście opisywania szczególnie dramatycznych wydarzeń, których bohaterami (i/lub ofiarami) byli Żydzi, np. szykany, wymierzanie kary, znęcanie się, selekcje, egzekucje, transport zagazowanych zwłok czy tzw. akcje dziecięce, w czasie których dzieci z pola kobiecego zabierane były do komór gazowych:

${ }^{63}$ Blokszrajber (niem. Block-Schreiber) - pisarz, więzień funkcyjny w baraku. 
W tym czasie [...] Żydówki już stacjonowały na naszym polu z dziećmi małymi [...] i myśmy tam flancowały kapustę. [...] W pewnym momencie myśmy usłyszały strzał. [...] Okazało się, że Aufzjerka zastrzeliła Żydówkę, która ze swoim synkiem, takim chłopcem pięcio-, może sześcioletnim, uciekała. Ona myślała, że ona ucieknie; ta ją zastrzeliła [...] i ona zmarła [...]; to ciało leżało parę godzin [...] wysiąkła krew tej niewiasty. [...] Przez [...] kilka dni padał deszcz, ta ziemia była bardzo wilgotna i ta krew tej Żydówki..., tak jakoś ona upadła [...] tak jak... jak... jakiś krzyż, i to zostało bardzo długo. Myśmy chodziły, ciągle ta krew nie wsiąkła w tę glinkę lessową, było to straszne przypomnienie. [J.B.]

Widziałam na własne oczy osoby wiezione po zagazowaniu na takich platformach ulicą lagrową do krematorium na piąte pole. Trupy były nieprzykryte, nagie ciała; w związku z ruchem wozów te trupy się ruszały: ręka spadła, noga..., więc wyglądało to..., wyglądały te trupy jak ludzie żywi. [H.B.-K.]

Zaobserwowane sceny są przez część świadków opisywane w sposób beznamiętny:

Kiedyś właśnie Żydów takich dwóch przyprowadzili, to ich tam od razu załatwili na polu gdzieś, tam na stacji w Lublinie, gdzieś tam, bo próbowali ucieczki. [Z.B.]

Większość narratorów opisuje je jednak w sposób pełen emocji - jako przeżycia mające dla nich szczególne znaczenie przede wszystkim ze względu na towarzyszące im silne uczucia (strach, rozpacz, poczucie bezradności, współczucie dla ofiar), jako wydarzenia „tragiczne”, „straszne” czy „makabryczne”, pozostawiające silny, niezatarty ślad w pamięci, będące źródłem prześladujących przez całe życie wspomnień:

Trzy dni mija, ja nie wiem. Żyję jak w jakiejś malignie. Tych, tych, tych, młode kobiety. To wszystko... dzieci do pieca. Do pieca. Śmieją się te Żydzi. Jakiś rabinek psalmy śpiewa. Jakieś erotyczne, erotyczne... gadka seksowa, erotyczna gadka na temat tych... na temat tych młodych, tych [...] tych gołych ciał. Tych Żydówek pięknych. [...] Ja to wszystko nie mogę znieść. [...] To strasznie mnie męczy, te wspomnienie. Jeszcze teraz, jeszcze teraz nieraz, cholera, mie to przychodzi. Jak wyszłem z Majdanka, to ciągle mie to gryźli. [...] Te krematorium. [...] Nie mogłem się pozbyć. Gdzieś mie to tkwiło. I po nocach ciągle widziałem... [K.W.]

Później były te straszne rzeczy związane z selekcjami i morderstwem dzieci. [...] Jak te Żydówki przyjechały pod koniec... w połowie kwietnia, po powstaniu w getcie, więc poprzywoziły te swoje dzieci. [...] I teraz te dzieciny małe, wszystko wylądowało na samochodach, [...] esesmani brali, zabierali tym... dzieci tym matkom. Maluchy to brali tak za nogi i rzucali $[\ldots]$ do tego wozu. [...] Jak nazbierali tego mnóstwo, wiele, to wtedy wyjeżdżali i pakowali ich do tej kamery gazowej. I te dzieciny wszystkie ginęły. [...] Było to nie do pomyślenia. [J.B.] 
Szczególnie silne emocje związane były z wypowiedziami odnoszącymi się do bestialskich zachowań załogi, mordowania dzieci żydowskich, egzekucji 3 listopada 1943 r. oraz dylematów moralnych związanych z sensem ratowania tych, którzy na Majdanku skazani są na śmierć:

To jest 3 listopad. Tragedia. Już nie wiem. Tam każdy chciał się coś dowiedzieć, ale to już... Nie miałem nawet gdzie spać. W ogóle nie było spania tam. Trochę się rozczuliłem przy tej historii, ale to już jest takie życie. [Z.Ć.]

Tak że wie pani, naprawdę nigdy nie było wiadomo, czy się robi dobrze, czy się robi źle. Ja zresztą nie mogę o tym mówić normalnie [płacze]. [J.W.]

\section{Do dyskursu traumatycznego zaliczyć należy także wspomnienia} przemocy i prześladowań, jakich sami narratorzy doświadczyli ze strony żydowskich więźniów funkcyjnych:

Po niedługim czasie komando nasze przeniesione zostało z pola trzeciego na pole pierwsze. I tu trafiliśmy do baraku, którego blokowym był Żyd ze Słowacji. I cała obsada w zasadzie tego bloku była... składała się z tych ludzi. Tam dostaliśmy szkołę życia na Majdanku. Blokowy potraktował nas jako braci. Z tym, że otoczył nas specjalną „sympatią”, mianowicie: dźwiganie kotłów to my, mycie podłóg to my. Wszystkie najcięższe prace na bloku na nas się składały. Z tym że na pierwszym polu już były prycze, już były koce, były podgłówki, ale to, co wydawałoby się udogodnieniem, stało się właściwie sposobem do zadręczania więźniów, ponieważ prycze musiały być idealnie równo posłane, wyrównane, i za źle posłaną pryczę dostawało się karę chłosty od blokowego po apelu wieczornym. [J.M.]

Po przebraniu trafiliśmy do bloku piątego po lewej stronie [...]. Blokowym był białostocki Żyd, tragarz Benio Feder, który bił nas i zabijał drągiem okutym po złamanej szufli. On nam... do nas się normalnie zwracał: „Słuchajcie skurczybyki, kupy, gnoje". I on miał swoistą filozofię obozową. Zelentowi powiedział: „Ty musisz umrzeć, żebym ja mógł żyć”. To było jego kredo obozowe. [...] Na Schonungsblocku ${ }^{64}$ był czeski Żyd Fredlich, morderca, który mordował tych ludzi, którym się udało [...] przetrzymać tyfus plamisty, po to, żeby zdobyć ich chleb. Jemu nie chodziło o chleb, on ten chleb sprzedawał, bo to była najwyższa wartość walorów obozowych, i zamieniał to sobie na jakieś rzeczy dla siebie. [A.S.]

Rekrutowali się oni [tj. więźniowie funkcyjni] przeważnie z pierwszych mieszkańców obozu spośród Żydów, bo w pierwszym rzędzie byli Żydzi przywożeni na teren Majdanka [...] z Węgier, Żydzi z Czechosłowacji... I muszę powiedzieć, że tak jak w mojej pamięci i w ogólnym przekroju, nie chciałbym generalizować tego, ale byli to ludzie, którzy też w imię ratowania własnej skóry łatwo poddawali się tej atmosferze sadyzmu, jaki towarzyszył w ogóle w postępowaniu w obozie. [...] To jest, moim zdaniem, jakiś morał, jakaś kwintesencja bytowania i warunków życia w obozie koncentracyjnym. Jeden zabijał drugiego w imię ratowania własnej skóry, w imię możliwości stworzenia sobie warunków. [T.O.]

${ }^{64}$ Schonungsblock (niem.) - blok dla rekonwalescentów. 
Wśród najważniejszych wątków dyskursu traumatycznego wskazać należy wspomnienia odnoszące się do akcji „Erntefest”, która ze względu na swój masowy charakter, sposób przeprowadzenia, liczbę zamordowanych oraz skutki i konsekwencje organizacyjne, jakie przyniosła polskim więźniom, jest ważnym elementem wspomnień znacznej liczby narratorów. Wydarzenie to silnie utkwiło w pamięci świadków i jest opisywane jako „pamiętny dzień”, „okrutna egzekucja”, doświadczenie „najcięższe i najbardziej przykre”, ,potworne”, „wstrząsające”, „okropne”:

Niestety przeżyłam trzeci listopada [1943 r.]. Dzień zagłady Żydów. Środa straszna. Tak zwane „Dożynki”. [E.W.]

[19]43 rok, proszę pani, to była... wsławił się, no [...] przeżyłem to w sposób, tak jak wszyscy więźniowie, pełen dramatu. Bo trzeciego listopada odbyła się ta... [...] okrutna egzekucja tych osiemnastu tysięcy Żydów. Proszę pani, to było o... ok... okropne. [J.K.]

Do elementów chyba najcięższych, najbardziej przykrych [...] należy dzień trzeciego listopada [1943 r.]. Dzień, w którym wymordowano na terenie obozu ponad osiemnaście tysięcy ludzi. Ludzi, których jedyną winą było to, że byli Żydami. [J.M.]

Padła komenda: „Alle Juden rechts austreten” - to znaczy: „Żydzi mają na prawo wystąpić". Ustawiono ich kolumną piątkową jak zwykle, tutaj, twarzą w kierunku bramy wyjściowej. [...] Ja potem wszedłem na trzecim polu do naszego pokoju [...] doszedłem do okna i przerażony stałem [...] doliczyłem się siedmiu kordonów ciężko uzbrojonych esesmanów. [A.S.]

Choć egzekucja listopadowa Żydów nie była doświadczeniem, które dotyczyło samych narratorów, niektórzy przedstawiają to wydarzenie jako coś, co dotknęło ich w bezpośredni sposób, jako „nieszczęście”, które „ich spotkało":

A więc to [tj. egzekucja 3 listopada], śmiało mogę stwierdzić, że to w mojej pamięci najwięcej utkwiło ze wszystkich nieszczęść, jakie mnie spotkały na terenie obozu. [M.G.]

W relacjach opisywane są sceny przemarszu Żydów prowadzonych spoza obozu:

Pędzono tysiące Żydów w kierunku piątego pola tą drogą tutaj z różnych podobozów, z jakichś gett. Konwojowali ich również żołnierze Wehrmachtu [...]. Niektórzy byli już śmiertelnie zmęczeni ci więźniowie. Przewracał się człowiek na ziemię, to taki wehrmachtowiec odbezpieczał karabin, strzelał go [...] i kolumna szła dalej. [A.S.]

Trzymają tak nas na apelu i widzimy, jak ze wszystkich stron Lublina chmary pędzą... prawda... kobiety, dzieci, mężczyzn, starców i tak dalej, i tak dalej. [...] 
No i esmani z jednej i z drugiej strony z psami, ujadanie psów, straszny zamęt, krzyk. [M.G.]

Stojąc na apelu, widzieliśmy, jak tam sznur, sznur, prawda, tych Żydów był prowadzony tą szosą piasecką do obozu. I tutaj wzdłuż obozu to przeszło, to było jakaś [jakieś] czarne... Czarna kolumna, długa, długa, długa kolumna. No, potem dowiedzieliśmy się, że to było, prawda, ponad osiemnaście tysięcy ludzi. [M.L.]

W wielu relacjach wspomnienie Zagłady przybiera formę doświadczenia o charakterze dźwiękowym: przywoływana jest muzyka połączona z terkotem karabinów maszynowych:

I nagle w pewnym momencie usłyszeliśmy z piątego pola dźwięki muzyki tanecznej z terkotem karabinów maszynowych [...]. Sądziliśmy, że jesteśmy w domu wariatów czy no... no... nie wiadomo gdzie. Zresztą była bardzo znamienna nasza reakcja, w tym momencie już [...] mieliśmy pewną świadomość, że Żydów poprowadzono na śmierć. [A.S.]

I świadomość tego, że tam ci ludzie giną, i te grające [...] głośniki. Piękne, straussowskie walce, a pomiędzy tym, prawda, w tej melodii się słyszało, prawda, ten terkot tych karabinów. Terkot karabinów. Zdawaliśmy sobie sprawę, co się dzieje. I to było przeżycie okropne dla nas. [K.W.]

W relacjach pojawia się wspomnienie lęku, niepokoju i niepewności, a w niektórych przypadkach także pewnej nadziei związanych z dniem 3 listopada 1943 r. - zaburzenie stałego porządku dnia w obozie mogło zwiastować bądź to nadchodzące wyzwolenie, bądź też zagładę wszystkich więźniów. W tych wspomnieniach uwidacznia się w sposób szczególny z jednej strony poczucie odmienności, z drugiej zaś wspólnoty losów z żydowskimi współwięźniami - z poczuciem zagrożenia i obawą, że więźniowie polscy zostaną zgładzeni w następnej kolejności ${ }^{65}$ :

I wtedy straszna jakaś taka bojaźń zapanowała w obozie, że teraz Żydów, a później nas. Więc chodziłyśmy, chodziliśmy - bo mówię i o mężczyznach - chodziliśmy z głową bolącą, apatyczni, załamani kompletnie po tym dniu strasznym. No później doszły do nas słuchy, jak to wszystko się odbywało. [E.W.]

Byliśmy przekonani, że będziemy tak zwanym drugim rzutem rozstrzelani przez Niemców. [A.S.]

Za dziesięć godzin wybili osiemnaście tysięcy, przeszło osiemnaście tysięcy Żydów. Tragedia. Co będzie z nami? [J.B.]

Mieliśmy świadomość tego, że oni są pierwsi [...] A my pójdziemy być może w drugiej kolejce. Z tą świadomością myśmy zawsze żyli. Nigdy tej pewności, że się wyjdzie. [M.L.]

${ }^{65}$ Zwrócił na to uwagę także Wojciech Lenarczyk, analizując grypsy (nielegalna korespondencja więźniów) potajemnie wysyłane z Majdanka: Lenarczyk, „Straszny strach”..., s. 89-97. 
Nie wiem, czy byłby jakiś reżyser, który potrafiłby to odtworzyć [...] ten strach, to przerażenie ludzi, którzy widzą przed sobą hordy esesmanów uzbrojonych po zęby i po... podchodzących [...] blisko i teraz człowiek pełen wątpliwości, czy to do nas, czy do kogo. Nie wiadomo. [...] Osiemnaście tysięcy. To od rana do wieczora to trwało. No niech... trudno mi opisać samopoczucie nas, [...] którzy siedzieliśmy na czwartym polu i słyszeliśmy te strzały, te tę okropną muzykę, no i niepewność... kto dalej? Co dalej? Kto następny? [J.K.]

No wcale nie było powiedziane, że za miesiąc czy za dwa w ten sam sposób nie wykończą wszystkich Polaków. Tym bardziej że oni [Niemcy] chyba mieli takie zamiary, których nie zdążyli urzeczywistnić, żeby nie pozostawić świadków obozu... [J.W.]

W kilku relacjach narratorzy przywołują poczucie bezradności i żalu, że nie udało się ocalić przynajmniej części współwięźniów żydowskich:

3 listopada [tysiąc dziewięćset] czterdzieści trzy [...] rewir z piątego pola natychmiast rano musiał być przeniesiony [...] na pole trzecie, bo na piątym była rzeź i przechodzili Żydzi przez przerwane druty do rowów tam na rozstrzelanie. I myśmy z rewiru, personel rewirowy z chorymi [...] szliśmy razem w kolumnie przez bramę z piątego na trzecie pole. I [...] w tę kolumnę powchodzili Żydzi, pracownicy rewiru. Wiedzieli, co się dzieje [...]. Konietzny [...] wiedział, kto Polak, kto Żyd. Wyłapywał [...] On mógł nie poznać, on mógł udać, że nie poznał. Ten Żyd by się przesunął z nami na trzecie pole [...] może by się udało w tym wielkim bałaganie po tym, po tym wszystkim, po tym zmienić winkiel ${ }^{66}$. [...] To wszystko było do zrobienia. [R.S.]

W innych relacjach opowiadają o donosach na Żydów ukrywających się w obozie na aryjskich papierach:

Ona podała listę kilku osób, które były na Majdanku na fałszywych papierach polskich, ale były to osoby z pochodzenia żydowskiego. I ona „zakapowała” - mówiąc językiem naszym, więziennym. Zakapowała i te osoby zostały wyłowione i poszły razem z tymi Żydówkami tam. Nie mam dowodu, że to była ona, dlatego nie chcę powiedzieć teraz głośno jej imienia i nazwiska. [H.B.-K.]

W relacjach pojawiają się też wspomnienia o reorganizacji obozu i zmianie sytuacji więźniów polskich, jaka nastąpiła po akcji „Erntefest”. Część rozmówców określa ten moment jako ważny czy wręcz „przełomowy", opowiadając o przejmowaniu przez Polaków stanowisk funkcyjnych po wymordowanych Żydach, możliwości pozyskania lepszej odzieży i poprawy warunków bytowych, a także złagodzenia reżimu obozowego:

${ }^{66}$ Winkiel (niem. Winkel - 'kąt, kątomierz') - w polskiej gwarze obozowej oznakowanie więźnia według konkretnej kategorii, naszywane na odzieży osadzonego w postaci trójkąta z tkaniny lub, jak w przypadku KL Lublin, także prostokąta. 
Na następny dzień zaczęły się funkcje przekazywane Polakom [...]. Dlatego że cały obóz, cała administracja była przeważnie prowadzona przez Żydów [ze Słowacji]. No i teraz obsadę zaczęli przejmować Polacy. Co nam dało możliwość lepszego ubrania się, dostania lepszej odzieży i dostania jakiejś funkcji. To już była sprawa bardzo ważna. [B.C.]

Po rozstrzelaniu Żydów, ludzi, przecież to ludzie, po może tygodniu czy dwóch tygodniach otrzymałem pracę w elektrowarsztacie. [...] Przedtem Żydzi byli w tym warsztacie. [A.Z.]

[Egzekucja 3 listopada] to był przełom w stosunkach na Majdanku. [...] Polacy zaczęli zajmować te komanda, gdzie można było coś skorzystać - jeden drugiego ciągnął, to był taki punkt przełomowy. [J.Ć.]

\section{Wnioski}

Analiza wywiadów wideo z byłymi więźniami polskimi Majdanka wymagała odniesienia się do zagadnień historycznych, do kwestii o charakterze politycznym i społeczno-kulturowym, a także do problematyki związanej $\mathrm{z}$ analizą wypowiedzi świadków historii traktowanych jako teksty kultury, ale też jako pewne konstrukty językowe. Konieczne było odwołanie się do literatury przedmiotu z obszaru różnych dyscyplin, jak również połączenie kilku strategii badawczych, przez co zastosowane podejście nabrało złożonego, wieloperspektywicznego charakteru i nie mogło być osadzone w ramach jednolitej konstrukcji teoretycznej. Przyjęta metodologia wydaje się jednakże adekwatna do określonych założeń i celów badawczych oraz do specyfiki materiałów źródłowych, jakimi są wywiady wideo.

Pomimo że zagadnienia dotyczące Żydów w obozie nie były zasadniczym tematem wywiadów, odniesienia do tej problematyki - wyrażone wprost lub mimochodem, spontanicznie lub w odpowiedzi na pytania prowadzącej - można znaleźć w części spośród zarejestrowanych relacji. We wspomnieniach zawarte są różnego typu informacje i dane dotyczące dziejów obozu i warunków życia więźniów. Relacje te stanowią interesujący materiał badawczy w sensie faktograficznym, należy je jednak postrzegać także jako źródła, w których odzwierciedlają się procesy konstruowania narracji o przeszłości zachodzące w specyficznych warunkach historycznych, pod wpływem różnego rodzaju czynników o charakterze społecznym i kulturowym.

Nawet pobieżna analiza treści analizowanego korpusu wywiadów wideo z byłymi polskimi więźniami, uwzględniająca przede wszystkim 
rejestrację pojawiania się w relacjach zagadnień dotyczących Żydów w KL Lublin i prowadzona w kontekście współczesnych opracowań historycznych, pozwala dostrzec pewne zniekształcenia na poziomie faktograficznym, a także obecność określonych tendencji, jeśli chodzi o sposób przedstawiania i interpretowania przywoływanych przez narratorów wydarzeń, zjawisk i procesów związanych z funkcjonowaniem obozu. Dotyczy to m.in. obecności na Majdanku więźniów różnych narodowości, wzajemnych stosunków i relacji między więźniami należącymi do poszczególnych grup etnicznych i narodowych, a także kwestii związanych z dokonującą się na Majdanku Zagładą. Choć - jak wiadomo z ustaleń współczesnych historyków - Żydzi z Polski i innych krajów europejskich stanowili około połowy więźniów i większość ofiar KL Lublin, w świetle analizowanych wywiadów można odnieść wrażenie, że obóz miał „typowo polski" charakter. Choć w wielu przeanalizowanych relacjach pojawiają się wspomnienia dotyczące Żydów, zwykle są one przywoływane w kontekście wydarzeń, które dla narratora były szczególnie przykre lub nadzwyczaj ważne w związku z osobistymi przeżyciami. W stosunkowo krótkich, trwających średnio ok. 60 minut rozmowach narratorzy skupiali się na przedstawianiu własnych doświadczeń, pomijając zazwyczaj wątki, które - jak można przypuszczać - uznawali za mniej istotne ${ }^{67}$. Wyjątkiem są traumatyczne wspomnienia dotyczące masowej egzekucji Żydów 3 listopada 1943 r., opisywanej zazwyczaj jako wydarzenie, które - ze względu na skalę i sposób przeprowadzenia akcji - dotknęło narratorów w sposób bezpośredni, pozostawiając niezatarty, bolesny ślad w pamięci.

Widoczne w wywiadach z polskimi świadkami przeinaczenia faktograficzne czy chronologiczne, a także przemilczanie określonych wątków, przy jednoczesnym uwypuklaniu innych, bądź też forsowanie - w sposób jawny lub zawoalowany - określonych tez odnoszących się do sytuacji w obozie odsłaniają polityczny, społeczny i kulturowy kontekst powstania relacji, a także subiektywny walor obozowych wspomnień. W wywiadach nagrywanych post factum, ponad 40 lat od opisywanych wydarzeń choć widoczne jest dążenie do porządkowania opowieści o obozowym doświadczeniu, oprócz informacji o faktach pojawiają się opinie, oceny, sądy, interpretacje, próby wyjaśniania i usprawiedliwiania zachowań

${ }^{67}$ Analiza porównawcza wywiadów przeprowadzonych pod koniec lat osiemdziesiątych z relacjami, które byli więźniowie składali w późniejszych latach zarówno w PMM, jak i w instytucjach zajmujących się dokumentowaniem historii Żydów podczas okupacji (np. USC Shoah Foundation w Los Angeles czy Muzeum Holocaustu w Waszyngtonie), oraz ze spisanymi przez nich wspomnieniami stanowi otwarty temat badawczy. 
własnych i innych osób oraz dążenie do przedstawiania indywidualnego spojrzenia na wydarzenia historyczne. Specyfika relacji mówionych, w których własne doświadczenia, przeżycia i emocje lokutorów przekazywane są za pośrednictwem języka potocznego, w mniejszym stopniu uporządkowanego niż w spisanych wspomnieniach czy tworzonych na potrzeby konkursów pamiętnikach, sprawia, że poszczególne kwestie prezentowane są spontanicznie, w perspektywie osadzonej w indywidualnej biografii świadka.

Analiza relacji wideo nagranych pod koniec lat osiemdziesiątych dla PMM pozwala stwierdzić, że w 7 spośród 41 przeanalizowanych wywiadów byłych więźniów - Polaków, nie pojawiają się żadne wzmianki o Żydach jako o odrębnej, znaczącej liczbowo grupie osadzonych. W wielu kolejnych relacjach żydowskim więźniom poświęcone są zaledwie pojedyncze zdania czy zdawkowe wzmianki. Pojawiają się też wspomnienia wydarzeń dotyczących Żydów (np. tzw. akcje dziecięce, selekcje, egzekucje), gdzie narratorzy przemilczają tożsamość ofiar lub jakby sugerują, że dotyczyły one Polaków.

Znaczna liczba relacji, w których informacje o żydowskich współwięźniach są nieobecne lub marginalizowane, co w prowadzonych analizach określone zostało mianem dyskursu nieobecności, może świadczyć o niewiedzy lub odzwierciedlać świadome bądź też nieświadome dążenie do kreowania narracji o obozowym doświadczeniu przez pryzmat indywidualnej biografii i losów własnej grupy, z pominięciem perspektywy więźniów innych narodowości, w tym Żydów. Wydaje się jednak, że dyskurs nieobecności w analizowanym zespole relacji można interpretować przede wszystkim jako wyraz powielania określonych schematów przedstawiania wydarzeń z czasów okupacji, zgodnych z polityką historyczną PRL, w ramach której nie dostrzegano i nie analizowano specyfiki sytuacji Żydów jako odrębnej grupy więźniów i w której wyraźne było dążenie do eliminowania Zagłady z dyskursu II wojny światowej.

Ważnym aspektem mogącym wpływać na formę i treść wywiadów jest fakt, iż wielu rozmówców Marii Brzezińskiej wspominało o swoich obozowych przeżyciach już po raz kolejny. Ich rola i zaangażowanie w działania edukacyjne i spotkania z młodzieżą (tzw. spotkania ze świadkiem historii) sprawiały, że - jak się wydaje - mogli postrzegać swoje zaangażowanie w projekt nagrywania wywiadów wideo przede wszystkim jako działanie mające służyć przekazywaniu konkretnych edukacyjnych 
treści o patriotycznym, heroicznym charakterze (walka, bohaterstwo, wysokie morale, ogrom cierpienia Polaków).

W analizowanych relacjach postacie żydowskich współwięźniów - czy dotyczy to grupy, czy też konkretnych osób - przywoływane są w kontekście określonych pojęć i kategorii oraz w odniesieniu do pewnego typu wydarzeń lub sytuacji. We wszystkich rodzajach dyskursów uwidacznia się - w większym lub mniejszym stopniu - pewnego rodzaju dystans, a także dążenie do kreowania wyraźnego rozgraniczenia między „żydowskimi” i „polskimi” więźniami. Obserwację tę potwierdza m.in. fakt, iż Żydzi przywoływani są zazwyczaj w sposób anonimowy - lokutorzy rzadko operują imionami czy nazwiskami, z wyjątkiem niektórych sytuacji, gdy relacjonujący opisuje osobę, z którą utrzymywał potajemnie głębsze, osobiste kontakty ${ }^{68}$.

Odrębność i oddzielenie są podkreślane także poprzez stwierdzenia wskazujące, że chociaż polscy więźniowie byli świadkami znęcania się nad Żydami przez załogę KL Lublin, wydarzenia związane z Zagładą były trzymane w tajemnicy przez załogę obozu - poszczególne sytuacje można było obserwować jedynie przypadkiem bądź z ukrycia.

Wątek różnicy i odmienności jest wyraźnie widoczny zarówno na poziomie faktograficznym, tj. związanym $\mathrm{z}$ opisem obrazu obozowego świata i relacjonowaniem konkretnych wydarzeń, gdzie Żydzi pojawiają się jako odrębna grupa więźniów wykonujących najcięższe prace i źle traktowanych przez załogę obozową, a przez to budzących współczucie, jak i na poziomie wypowiedzi z wyraźnie zaznaczonymi podmiotami zbiorowymi: „my” i „oni”. Rozróżnienia: „my”/,Żydzi”, „więźniowie”/,Żydzi”, pogłębiają wrażenie podziału, izolacji i marginalizacji tych ostatnich, podczas gdy konstrukcje językowe wskazujące na poczucie wspólnoty losów między żydowskimi i polskimi osadzonymi pojawiają się w nielicznych relacjach: „nasi współwięźniowie Żydzi”, „oni cierpieli tak jak my”.

Fragmenty wspomnień byłych więźniów Majdanka dotyczące Żydów więzionych i mordowanych w obozie, zebrane i odczytywane jako odrębny korpus tekstów, wykraczają poza subiektywny charakter opowieści o indywidualnym doświadczeniu, budują złożoną, wielowątkową, choć niejednolitą narrację. Obraz obozowych przeżyć lokutorów analizowany w kontekście relacji między polskimi i żydowskimi więźniami, pomimo

${ }^{68}$ Do podobnych wniosków doszła także Alina Cała, analizując 184 wywiady z Polakami z lat 1975-1984 dotyczące ich relacji z Żydami. Zob. Alina Cała, Wizerunek Żyda w polskiej kulturze ludowej, Warszawa 2005, s. 52-53. 
iż budowany w odniesieniu do faktycznych doświadczeń i mający - m.in. ze względu na sposoby opisywania postaci i wydarzeń - wymiar realności i konkretności, stanowi konstrukcję uwarunkowaną przedwojenną i powojenną biografią, wiedzą, emocjami, postawami i przekonaniami narratorów, a także politycznymi, społecznymi i kulturowymi uwarunkowaniami związanymi z procesem nagrywania relacji.

Konstruowany przez narratorów obraz obozowej rzeczywistości w wielu wypadkach całkowicie pozbawiony odniesień do obecności więźniów żydowskich - nosi znamiona „świata wyobrażonego”, budowanego niejednokrotnie na podstawie schematycznych, stereotypowych ujęć, gdzie Żydzi ukazywani są jako odrębna, dość zwarta, lecz niejednorodna grupa, której członkowie, wyróżniający się wyglądem (uroda, strój, oznaczenie gwiazdą Dawida) oraz językiem, posługują się odmiennym systemem wartości.

Analiza zagadnień dotyczących budowania narracji o życiu w obozie, gdzie zasadniczym punktem odniesienia jest kategoria różnicy oraz kulturowo uwarunkowane wyobrażenia, tworzące instrument narracyjnego marginalizowania i wykluczania z opowieści o KL Lublin określonej grupy (grup) więźniów, może stanowić przedmiot dalszych badań. Podkreślanie odrębności osadzonych żydowskich można postrzegać jako istotne dla samookreślenia się narratorów jako przynależnych do grupy „więźniów” (np. Polaków osadzonych z powodów politycznych, reprezentujących określone normy i wzory kulturowe) wobec „Żydów” (tj. grupy odrębnej pod względem etnicznym i obyczajowym, mającej odmienny status w obozie). Więźniowie żydowscy, których obraz niejednokrotnie przyjmuje w przekazach uogólniony, „zbiorowy” charakter, stanowią w wielu relacjach swego rodzaju „tło” dla opowieści o doświadczeniu narratora i reprezentowanej przezeń grupy. Ujęcie to może być także postrzegane jako wyraz dążenia do porządkowania przez narratorów własnych doświadczeń nie tylko w odniesieniu do kwestii etnicznych i narodowych, ale też w kontekście ugruntowanych w kulturze wyobrażeń dotyczących Żydów. Zjawisko to jest widoczne m.in. w przypadku dyskursu traumatycznego, zwłaszcza w opowieściach poświęconych akcji „Erntefest”, gdzie narratorzy podkreślają bierność Żydów „idących na rzeź” i „pędzonych w kierunku krematorium”, stawiając takie zachowania w opozycji do domniemanych heroicznych postaw Polaków, którzy „woleliby raczej zginąć w walce" i którzy podejmują walkę o zachowanie godności. 
Wydaje się, że w podobnym kontekście odczytywać można także wypowiedzi narratorów, w których charakteryzują oni własne postawy i zachowania wobec żydowskich więźniów. Choć jako dominujące wskazać można: współczucie, żal i poczucie bezsilności, pojawiają się też emocje negatywne, skierowane do niektórych spośród żydowskich funkcyjnych źle traktujących Polaków, oraz pewnego rodzaju niechęć do wykształconych Żydów słowackich zajmujących - do jesieni 1943 r. - stanowiska w administracji KL Lublin.

Próba analizy sposobów, w jakich byli polscy więźniowie Majdanka przedstawiają sytuację Żydów w obozie, wymagała rozważenia i uwzględnienia zagadnień dotyczących językowej ekspresji doświadczeń, sposobów prezentowania określonych wydarzeń, a także analizowania znaczenia konkretnych faktów i przeżyć dla biografii jednostkowych. Ze względu na subiektywny charakter wypowiedzi wszelkie przemilczenia i przeinaczenia faktograficzne były tu traktowane jako wyraz określonych sposobów rozumienia, interpretowania i konstruowania narracji o przeszłości. Odwołując się do indywidualnej pamięci i jej mechanizmów, odzwierciedlają one jednocześnie proces kształtowania się pamięci zbiorowej pod wpływem uwarunkowań politycznych, społecznych i kulturowych, w szerszym kontekście zaś mogą być postrzegane także jako źródła pozwalające analizować formy i sposoby mitologizacji przeszłości oraz kulturowe koncepcje świata leżące u podstaw tożsamości jednostek i grup.

\section{Bibliografia}

\section{1. Źródła archiwalne}

Archiwum Państwowego Muzeum na Majdanku

Archiwum Zakładowe, sygn. I/3, I/44, 66/15, 66/64, 66/86.

Nagrania audio, sygn. VIII-151.

Zbiór nagrań audiowizualnych, sygn. XXII, Nagrania: 1-67.

\section{2. Źródła opublikowane}

„Gazeta Robotnicza” (15 marca 1947).

"Głos Ludu” (22 grudnia 1944).

„Kurier Codzienny” (6 grudnia 1945).

Obóz zagłady w Bełżcu w relacjach ocalonych i zeznaniach polskich świadków, red.

Robert Kuwałek, Dariusz Libionka, Lublin 2013.

„Robotnik" (5 stycznia 1945). 


\section{Opracowania}

Akcja Reinhardt. Zagłada Żydów w Generalnym Gubernatorstwie, red. Dariusz Libionka, Warszawa 2004.

Banach Krzysztof, Działalność wystawiennicza Państwowego Muzeum na Majdanku w latach 1944-2014, „Zeszyty Majdanka” 26 (2014).

Banach Krzysztof, Dzielnice Zagłady. Niemieckie getta dla Żydów w okupowanym Lublinie, Lublin 2017.

Banach Krzysztof, Zagłada Żydów w świetle ekspozycji stałych Państwowego Muzeum na Majdanku, „Studia Judaica” 16 (2013), nr 2.

Berenstein Tatiana, Rutkowski Adam, Żydzi w obozie koncentracyjnym Majdanek (1941-1944), „Biuletyn ŻIH” 58 (1966).

Bilewicz Michał, Społeczna pamięć Holokaustu i Auschwitz wśród licealistów: wokót projektu badawczego „Trudne pytania”, [w:] Auschwitz i Holokaust. Dylematy $i$ wyzwania polskiej edukacji, red. Piotr Trojański, Oświęcim 2008.

Bornus Aleksy, Społeczność więźniów w świetle ich pamiętników, [w:] Majdanek 1941-1944, red. Tadeusz Mencel, Lublin 1991.

Cała Alina, Wizerunek Żyda w polskiej kulturze ludowej, Warszawa 2005.

Dziadosz Edward, Stosunki handlowe obozu koncentracyjnego na Majdanku z firma Paula Reimanna, „Zeszyty Majdanka” 2 (1967).

Erntefest 3-4 listopada 1943 - zapomniany epizod Zagłady, red. Wojciech Lenarczyk, Dariusz Libionka, Lublin 2009.

Filipkowski Piotr, Historia mówiona i wojna. Doświadczenie obozu koncentracyjnego w perspektywie narracji biograficznych, Wrocław 2010.

Forecki Piotr, Od Shoah do strachu. Spory o polsko-żydowska przeszłość i pamięć $w$ debatach publicznych, Poznań 2010.

Gicewicz Ryszard, Obóz pracy w Poniatowej, „Zeszyty Majdanka” 10 (1980).

Grudzińska Marta, Dionyz Lénard. Relacja z pobytu w obozie na Majdanku (kwiecień-czerwiec 1942 roku), „Zeszyty Majdanka” 26 (2014).

Grudzińska Marta, Los Żydów w obozie koncentracyjnym na Majdanku, [w:] Losy Żydów z Krasnegostawu i okolic. Zbiór artykułów i scenariuszy zajęć z zakresu antydyskryminacji i edukacji o Zagładzie, red. Lena Bielska, Katarzyna Zabratańska, Lublin 2016.

Grudzińska Marta, Los Żydów ze Słowacji deportowanych na Majdanek, „Judaica et Holocaustica” 4 (2015).

Grudzińska Marta, Obraz relacji między więźniami różnych narodowości w obozie koncentracyjnym na Majdanku, „Zeszyty Majdanka” 26 (2014).

Grudzińska Marta, Więźniowie z Majdanka deportowani do KL Plaszow w kwietniu 1944 roku, [w:] Płaszów. Odkrywanie, Kraków 2016.

Grudzińska Marta, Wstęp, [w:] Przewodnik po zbiorze relacji i pamiętników znajdujących się w zasobie Państwowego Muzeum na Majdanku, Lublin 2011.

Grudzińska Marta, Wywiady z bytymi więźniami jako nośniki pamięci o losach ludzi i historii miejsca. Historia mówiona w Archiwum Państwowego Muzeum na Majdanku, [w:] Historia mówiona $w$ świetle nauk humanistycznych, red. 
Joanna Szadura, Stanisława Niebrzegowska-Bartmińska, Mirosław Szumiło, Lublin 2014.

Grudzińska Marta, Zbiór „Nagrania audio” w zasobie Archiwum Państwowego Muzeum na Majdanku, „Zeszyty Majdanka” 25 (2011).

Grudzińska Marta, Żydzi słowaccy w obozie koncentracyjnym na Majdanku, „Studia Żydowskie. Almanach" 4 (2014).

Grudzińska Marta, Ciesielska Maria, Lekarze w pasiakach. Stużba medyczna na Majdanku. Wystawa internetowa, http://lekarze-w-pasiakach.majdanek.eu/pl/ lekarze-lekarze-stomatolodzy-i-studenci-medycyny-na-majdanku/ [dostęp: 2 października 2017].

Grudzińska Marta, Rezler-Wasielewska Violetta, Lublin, Lipowa 7. Obóz dla Żydów - polskich jeńców wojennych (1940-1943), „Kwartalnik Historii Żydów” (2008), nr 4.

Helling Ingeborg, Metoda badań biograficznych, [w:] Metoda biograficzna w socjologii, red. Jan Włodarek, Marek Ziółkowski, Warszawa 1990.

Kaźmierska Kaja, Wywiad narracyjny jako jedna z metod w badaniach biograficznych, „Przegląd Socjologiczny” 53 (2004), nr 1.

Kersten Krystyna, Polacy, Żydzi, komunizm. Anatomia pótprawd 1939-1968, Warszawa 1992.

Korzeniowski Bartosz, Przemiany obrazu drugiej wojny światowej w polskich muzeach po roku 1989, [w:] Druga wojna światowa w pamięci kulturowej w Polsce i w Niemczech 70 lat później (1945-2015), red. Jerzy Kałążny, Amelia Korzeniewska, Bartosz Korzeniewski, Gdańsk 2015.

Kranz Tomasz, Eksterminacja Żydów na Majdanku i rola obozu w realizacji „Akcji Reinhardt”, „Zeszyty Majdanka” 22 (2003).

Kranz Tomasz, Zagłada Żydów w obozie koncentracyjnym na Majdanku, Lublin 2010.

Kryl Miroslav, Deportacja więźniów teresińskiego getta do obozu koncentracyjnego na Majdanku w 1942 roku, „Zeszyty Majdanka” 11 (1983).

Kucia Marek, Auschwitz jako fakt społeczny. Historia, współczesność i świadomość społeczna KL Auschwitz w Polsce, Kraków 2005.

Kucia Marek, Optymistyczne dane - niepokojace pytania - radykalne wnioski, [w:] Auschwitz i Holokaust. Dylematy $i$ wyzwania polskiej edukacji, red. Piotr Trojański, Oświęcim 2008.

Kurkowska-Budzan Marta, Antykomunistyczne podziemie zbrojne na Białostocczyźnie. Analiza współczesnej symbolizacji przeszłości, Kraków 2009.

Kuwałek Robert, Były obóz koncentracyjny na Majdanku i miejsca po obozach zagłady na Lubelszczyźnie w prasie i świadomości mieszkańców (1944-1956), [w:] Słowa w stużbie nienawiści, red. Alicja Bartuś, Oświęcim 2013.

Kuwałek Robert, Nowe ustalenia dotyczace liczby ofiar niemieckiego obozu zagłady w Sobiborze, „Zeszyty Majdanka” 26 (2014).

Kuwałek Robert, Obozy koncentracyjne i obozy zagłady jako miejsca pamięci, [w:] Następstwa zagłady Żydów. Polska 1944-2010, red. Feliks Tych, Monika Adamczyk-Garbowska, Lublin 2011.

Kuwałek Robert, Obóz zagłady w Betżcu, Lublin 2010. 
Kuwałek Robert, Obóz zagłady w Sobiborze w historiografii polskiej i obcej, „Zeszyty Majdanka” 21 (2001).

Kuwałek Robert, Zbrodnie w Lesie Krepieckim w świetle zeznań świadków, „Zeszyty Majdanka” 21 (2001).

Kuwałek Robert, Żydzi lubelscy w obozie koncentracyjnym na Majdanku, „Zeszyty Majdanka” 22 (2003).

Kuwałek Robert, Wysok Wiesław, Lublin. Jerozolima Królestwa Polskiego, Lublin 2001.

Langer Lawrence L., Świadectwa Zagłady. Wrumowisku pamięci, tłum. Marcin Szuster, Warszawa 2015.

Lenarczyk Wojciech, Obóz pracy na Flugplatzu w Lublinie. Historia, funkcjonowanie, więźniowie, „Zeszyty Majdanka” 26 (2014).

Libionka Dariusz, Zagłada Żydów w Generalnym Gubernatorstwie. Zarys problematyki, Lublin 2017.

Madajczyk Czesław, Lubelszczyzna w polityce okupanta, „Zeszyty Majdanka” 2 (1967).

Marszałek Józef, Konspiracja w obozie, [w:] Majdanek 1941-1944, red. Tadeusz Mencel, Lublin 1991.

Marszałek Józef, Majdanek. Obóz koncentracyjny w Lublinie, Lublin 1981.

Masowe egzekucje Żydów 3 listopada 1943 r. Majdanek, Poniatowa, Trawniki, oprac. Edward Dziadosz, Lublin 1988.

Matczuk Alicja, Kranz Tomasz, Bibliografia publikacji pracowników Państwowego Muzeum na Majdanku, Lublin 2004.

Między codziennością a wielką historią. Druga wojna światowa w pamięci zbiorowej społeczeństwa polskiego, [Aut.] Piotr T. Kwiatkowski, Lech Nijakowski, Barbara Szacka, Andrzej Szpociński, Gdańsk-Warszawa 2010.

Murawska Zofia, Kobiety w obozie koncentracyjnym na Majdanku, „Zeszyty Majdanka" 4 (1969).

Przybyli do getta... Odeszli w nieznane... Zagłada Żydów w Generalnym Gubernatorstwie, red. Robert Kuwałek, Dariusz Libionka, Lublin 2013.

Siwek-Ciupak Beata, Kolekcja nagrań wideo z relacjami byłych więźniów Majdanka, „Zeszyty Majdanka” 24 (2008).

Steinlauf Michael, Pamięć nieprzyswojona. Polska pamięć Zagłady, tłum. Agata Tomaszewska, Warszawa 2001.

Stolarz Agata, Historia mówiona w warsztacie historyka mentalności, „Pamięć i Sprawiedliwość" (2012), nr 2.

Stolarz Agata, Podróż do Mezeritch. O doświadczeniu historii mówionej, „Wrocławski Rocznik Historii Mówionej” 4 (2014).

Tomaszewski Jerzy, Początki prześladowania Żydów słowackich, „Zeszyty Majdanka” 11 (1983).

Toniak Adela, Korespondencja w sprawie dostawy gazu cyklonu B do obozu na Majdanku, „Zeszyty Majdanka” 2 (1967).

Trojański Piotr, Upolitycznienie i instrumentalizacja pamięci ofiar Auschwitz (19461955), [w:] Słowa w stużbie nienawiści, red. Alicja Bartuś, Oświęcim 2013. 
Wiśniewska Anna, Rajca Czesław, Działalność naukowa Państwowego Muzeum na Majdanku, „Zeszyty Majdanka” 16 (1995).

Wóycicka Zofia, Przerwana żałoba. Polskie spory wokót pamięci nazistowskich obozów koncentracyjnych i zagłady 1944-1950, Warszawa 2009.

Zychowicz Jacek, Historiografia Auschwitzu: od krytycznej negacji do instrumentalizacji, [w:] Pamięć Shoah. Kulturowe reprezentacje i praktyki upamiętniania, red. Tomasz Majewski, Anna Zeidler-Janiszewska, Maria Wójcik, Łódź 2009.

Marta Grudzińska

Państwowe Muzeum na Majdanku, Lublin m.grudzinska@majdanek.eu

Marta Kubiszyn

Uniwersytet Marii Curie-Skłodowskiej, Lublin marta.kubiszyn@poczta.umcs.lublin.pl 